\title{
Паратекстуальные полонизмы в Псалтыри 1683 г. в переводе Аврамия Фирсова
}

\author{
ЛЮДМИЛА ГАРБУЛЬ \\ Romanų kalbų katedra, Užsienio kalbų institutas, Vilniaus universitetas, \\ Universiteto g. 5, LT-01513 Vilnius \\ E-mail: liudmila.garbul@flf.vu.lt
}

(Received: 24 August 2015; accepted: 12 October 2015)

\begin{abstract}
This paper is intented to analyze the lexical and semantic Polonisms identified in "The Translator's Explication" and "The Preface to the Reader", which precede the text of the Psalter 1683 in the translation of A. Firsov. The publication deals with 29 lexemes, with 18 of them being lexical borrowings. In two cases, they are not direct borrowings (cf. глупьй and читатель), but, most probably, are the result of the stimulating influence of the Polish language. According to the author, 11 words under analysis can be called semantic Polonisms. The paper also defines the role of the written language of the Grand Duchy of Lithuania in the process of the borrowing of these lexical elements. On the basis of the results of the analysis of the corpus, the author also touches upon the question of the translator's personality, which has remained debatable up to the present day.

Keywords: paratext, paratextual Polonisms, lexical Polonisms, semantic Polonisms, the Grand Duchy of Lithuania
\end{abstract}

\section{1. Вводные замечания}

В течение нескольких последних десятилетий объектом нашего внимания было изучение влияния польского языка на дипломатическую документацию Московского государства в XVII в. Связано это с тем, что дипломатическая корреспонденция занимала особое место в составе приказной письменности, а эта разновидность делового языка играла важную роль в становлении русского литературного языка нового типа. При этом именно посольская переписка в силу своей открытости для всякого рода воздействий была практически единственным возможным видом фиксации различных отклонений, в том числе и иноязычного влияния (в XVI-XVII вв., в частности, польского), от норм книжного (церковнославянского) языка, что в свою очередь создавало предпосылки для проявления такого влияния в других сферах языковой деятельности, а именно в книжном языке Московской Руси (см. Живов 1986: 259).

В конце XVII - первой половине XVIII в. на великорусской территории предпринимаются попытки создания произведений, которые, по свидетельству их авторов или переводчиков, написаны на «простом» языке (см. УСпенский 2002: 490-492). Следует обратить внимание и на то, что переводчикам 
в этот период рекомендовалось ориентироваться на язык документов Посольского приказа, в частности это касается истории перевода Ф. Поликарповым «Географии генеральной» Б. Варения в 1716-1718 гг. (Успенский 2002: 494495). Одним же из первых опытов создания «простого» языка на великорусской почве является «Псалтырь 1683 г.» в переводе Аврамия Фирсова (далее ПсФ), которая представляет для нас особый интерес по ряду причин. Во-первых, потому что А. Фирсов, переводивший Псалтырь, по его словам, на «простои, обыклои, словенскои языкъ» (ПсФ: л. 1), активно пользовался польскими текстами (см. ЦЕлуновА 2006: 8). Во-вторых, в связи с существующим предложением о том, что Аврамий Фирсов, возможно, был переводчиком Посольского приказа (библиографию по этому вопросу см. ИСАчЕНКО 1985: 179, ЦЕлуновА 2006: 21-23).

Изучению языка ПсФ, в том числе отражению в нем польского влияния, посвящен ряд исследований последней четверти XX - начала XXI вв. (см. ИСАЧЕНКО-ЛИСОВАЯ 1984: 248-257, ИСАЧЕНКО-ЛИСОВАЯ-ЛИСОВОЙ 1987: 68107, ЦЕлУнова 2006: 38-136). Т. А. Исаченко и Е. А. Целунова выявили в тексте ПсФ в общей сложности около 150 лексических и семантических полониЗмов (ИСАЧЕНКО 1987: 75-93, ЦЕЛУНОВА 2006: 128-134), что, по данным Е. А. Целуновой, которая обнаружила немногим более 100 полонизмов, составляет 3\% от лексического состава ПсФ (ЦЕлуновА 2006: 132). Т. А. Исаченко, анализировавшая лексические полонизмы в тексте ПсФ, обратила внимание на то, что в переводе, помимо текстуальных заимствований из польского, есть слова, употребление которых можно объяснить только тем, что они были в активном словаре самого переводчика (ИсАченко 1987: 96). К таким полонизмам она относит лексемы, которые засвидетельствованы в предисловии переводчика и в маргиналиях (ИсАченко 1987: 96-97). Иначе говоря, этот автор выделяет полонизмы, встречающиеся в паратексте ПсФ, и отмечает, что они заслуживают особого внимания. Мы полностью разделяем это мнение. На наш взгляд, обращение к паратексту ПсФ дает возможность не только выявить те полонизмы, которые могли составлять активный словарь переводчика, но может также пролить некоторый свет на личность А. Фирсова, поскольку достоверных биографических данных о нем пока не обнаружено (см. ИСАчЕНКО 1985: 178-179). В этом плане, по нашему мнению, показательны такие части текста, как запись, указывающая место и время перевода, а также имя переводчика Псалтыри (ПсФ: л. 1), «Объяснение переводчика» (ПсФ: лл. 3-4 об.), «Предисловие к читателю» (ПсФ: лл. 5-8 об.).

В настоящей публикации мы анализируем лексические и семантические полонизмы, обнаруженные в указанных выше частях текста ПсФ. При этом полонизмы, выявленные впервые, подвергаются детальному историко-этимологическому анализу, а заимствования из польского, рассматривавшиеся в предшествующих исследованиях, в основном сопровождаются отсылкой к соответствующим публикациям, причем в ряде случаев мы уточняем и дополняем эту информацию, опираясь на новейшие работы по этимологии, исторической лексикологии и лексикографии славянских языков. 


\section{2. Лексические полонизмы}

Въдомость [3] ${ }^{1}$ ж. Знание, осведомленность о чем-л.; осведомление: «Свидътелствована сия... книга со многихъ печатныхъ книгъ: ради истиныя въдомости... и увърения... простых людеи» (ПсФ: л. 3 ). ${ }^{2}$ «Не токмо простыя, но и духовнаго чина: истинныя въдомости ... во святомъ писании не ищут» (ПсФ: л. 3). «В неи убо // истинная въдомость, о величествђ престола божия» (ПсФ: лл. 5 об.-6).

Причисление этой лексемы к полонизмам не вызывает сомнений, ибо подтверждается целым рядом исследований (WITKOWSKI 2006: 22, ЦЕлуновА 2006: 124, 132; Аникин 6: 168-169, ГАРБУль 2014: 25), можно лишь уточнить пути ее проникновения в русский письменный язык. В русской деловой письменности рассматриваемое существительное фиксируется спорадически уже в 50-60-е гг. XVI в. (КоснмаN 1971: 44, СОРЯ 2: 54-55), а более широко с начала XVII в. (ГАРБуль 2014: 25). В памятниках Великого княжества Литовского (далее ВКЛ) въдомость в отмеченном в ПсФ значении - с середины последней четверти XVI в. (БулыкА 1980: 37, ГСБМ 3: 58, СУМ 6: 130-131). Сопоставление приведенных хронологических данных позволяет предполагать посредничество письменности ВКЛ при заимствовании слова въдомость в русский язык (см. ГАРБУль 2014: 25).

Гересь [1] ж. Ересь, религиозное учение, враждебное господствующей религии, противоречащее церковным догматам: «А которыя новоправленыя книги со старых // ...новыми книгами и гересию их называют» (ПсФ: л. 3 об.).

Это существительное, первоисточником которого является греческое hairesis 'выбор' > 'отбор', 'школа; секта' (см. ФАСмеР 1: 24, ЧерныХ 1: 285, ЭСлРЯ 5: 261-262), в форме, отмеченной в объяснении А. Фирсова к переводу «Псалтыри», является полонизмом, ${ }^{3}$ на что указывает и фонетическое оформЛеНИе сЛОВа (ИСАЧЕНКО-ЛИСОВАЯ 1984: 253-254, ИСАЧЕНКО-ЛИСОВАЯЛисовой 1987: 96, ЦЕлуновА 2006: 130). По замечанию Т. А. Исаченко (см. ИСАЧЕНКО-ЛИСОВАЯ-ЛИСОВОЙ 1987: 102), здесь видим влияние «простой мовы» в ее белорусском варианте, однако, согласно новейшим данным, гереза, герезия, герезьля 'єресь, релігійне вчення, що заперечує догми та організаційні

\footnotetext{
${ }^{1}$ Здесь и далее цифрой в скобках указывается количество употреблений лексемы в анализируемых нами фрагментах текста.

2 При цитировании текст источника воспроизводится следующим образом: графика упрощается в соответствии с правилами, принятыми в «Словаре русского языка XI-XVII вв.», орфографическая система и пунктуация памятника сохраняются, выносные буквы вносятся в строку, титла раскрываются, предлоги пишутся в соответствии с современным словоделением, в начале предложения используются заглавные буквы, усечения начала и конца цитаты не обозначаются, конец листа обозначается двумя косыми черточками (СлРЯ XI-XVII вв. 1: 15).

${ }^{3}$ В польский язык это существительное было заимствовано через латинское посредничество, где haerěsis 'учение, школа; система, научное направление', 'секта', среднелатинское haeresia - 'то же' (см. BRÜCKNER 1974: 171, SŁAWSKI 1: 417).
} 
форми панівної церкви', известное в памятниках ВКЛ с конца XVI - начала XVII в. и считающееся полонизмом (см. БулыкА 1972: 81, БулыкА 1980: 177, ГСБМ 6: 272), отмечается также в документах, исходящих из Киева и Львова (СУМ 6: 204-205). Внесенное нами уточнение отнюдь не отрицает возможности посредничества письменности ВКЛ при проникновении гересь в русский письменный язык XVII в., а лишь показывает, что в данном случае влияние «простой мовы», видимо, не следует ограничивать рамками ее белорусского варианта.

Польский источник рассматриваемой лексемы в восточнославянских языках надежно подтверждается хронологическими данными: в польской письменности herezis, herezyja 'świadome i dobrowolne zaprzeczenie przez człowieka ochrzczonego pewnych prawd wiary Kościoła, do którego on w jakiś sposób należy’ засвидетельствовано с середины 60-х гг. XVI в. (SłP XVI 8: 331, 331-332).

Геретикь [1] м. Еретик, последователь ереси; вероотступник: «И ученых людеи поносятъ... и геретиками их называют» (ПсФ: л. 3 ).

Это существительное, восходящее к греческому hairetikos 'выбирающий’ > 'вызывающий разделение, раскол' (см. ФАСмЕР 2: 24, ЧЕРных 1: 285), в той форме, в которой оно обнаружено в объяснении А. Фирсова к переводу «Псалтыри», является заимствованием из польского ${ }^{4}$ (см. СоБоЛЕВСКий 1903: 83, ИСАЧЕНКО-ЛИСОВАЯ 1984: 253-254, ИСАЧЕНКО-ЛИСОВАЯ-ЛИСОВОЙ 1987: 96, ЦЕлУновА 2006: 131, WiтKOWSKI 2006: 33), куда оно попало из латыни (haereticus 'сектант, отщепенец') (см. BRÜCKNER 1974: 171, SŁAWSKI 1: 416). Как и в случае с гересь, следует уточнить замечание Т. А. Исаченко, объясняющей употребление геретикъ влиянием «простой мовы» в ее белорусском варианте (ИСАЧЕНКО-ЛИСОВАЯ-ЛиСОвОЙ 1987: 102). ДеЛо в том, что геретикъ, геретыкъ 'єретик, відступник від догм панівної релігії', известное в актовом языке ВКЛ с 80-90-х гг. XVI в. и считающееся полонизмом (БулыкА 1972: 81, БулыкА 1980: 170, ГСБМ 6: 272), с начала XVII в. регистрируется также в документах, исходящих из Киева, Львова, Чернигова (СУМ 6: 205, SŁAwsKi 1: 416). О польском источнике анализируемой лексемы в деловой письменности ВКЛ и «простой мове» достаточно убедительно свидетельствуют хронологические данные: в польских источниках heretyk 'twórca lub wyznawca twierdzeń religijnych, wywodzących się z chrześcijaństwa, niezgodnych z nauką Kościoła rzymsko-katolickiego’ регистрируется с середины 40-Х гг. XVI в. (SłP XVI 8: 328-331).

Представленная выше информация подтверждает высказанное Т. А. Исаченко предположение о том, что слово геретикъ в русский письменный язык XVII в. могло попасть из польского через посредничество письменности ВКЛ.

\footnotetext{
${ }^{4}$ Примечательно, что и в заимствованном из греческого языка через старославянский еретик, но с ударением на втором слоге - ере́тик также усматривается польское влияние (см. ЭСлРЯ 5: 262, БАС 5: 538). С таким ударением, но только в переносных значениях эта лексема отмечается в русских говорах (СРНГ 9: 22).
} 
Однако новые факты о территории распространения геретикъ и геретыкъ в ВКЛ не позволяют однозначно утверждать, что мы имеем дело с влиянием «простой мовы» именно в ее белорусском варианте.

Глупство [1] c. Глупость, неразумие; ограниченность, недостаток: «И таковаго ради их невђждества, и грубости, и глупства... бывают нынђ в россииском господарствђ несогласия, расколы» (ПсФ: л. 3 об.).

Существительное глупство, впервые зарегистрированное в «Истории о великом князе Московском» А. Курбского (СлРЯ XI-XVII вв. 4: 38), относится к несомненным полонизмам в русском языке (см. КоснмаN 1975: 6061, ИСАЧЕНКО-ЛИСОВАЯ-ЛИСОВОЙ 1987: 77, ЦЕЛУНОВА 2006: 125, WitкоWsKi 2006: 35). В данном случае необходимо лишь уточнить пути его проникновения в русскую письменность.

В польских письменных источниках glupstwo 'głupota, brak rozumu, szaleństwo; nieuctwo, prostactwo (czasem czyn lub słowa świadczące o głupocie)’ наблюдается с 30-40-х гг. XVI в. (SłP XVI 7: 440). В актовом языке ВКЛ глупство, кглупство представлено с конца 70-х гг. того же столетия, а в текстах на «простой мове» - с конца XVI - начала XVII в. (ГСБМ 6: 300-301, СУМ 6: 224-225) и квалифицируется как заимствование из польского языка (ЭСБМ 3: 96).

Сопоставление приведенной выше информации позволяет говорить о том, что рассматриваемая лексема проникла в русскую письменность XVIXVII вв. из польского, вероятнее всего, благодаря посредничеству делового языка ВКЛ и «простой мовы».

Глупый [4] прил. 1. Умственно ограниченный, недалекий, неумный; невежественный, несведущий (3): «И во всем дияволском злом собрании таино тамо живутъ... и... глуnыx, и неученых людеи, своимъ ложным дияволским злым учением, прелщаютъ» (ПсФ: л. 4). «А неученыя простыя, и глупья люди, их злои прелести дияволскои, вьрятъ» (ПсФ: л. 4); субст. «Многия суть и такия простыя невђжди, и глупыя обрђтаются, в нынђшния наши времена» (ПсФ: л. 3 об.); 2. Лишенный разумного содержания; бессмысленный (1): «Глупое дъло, еже читат, а не разумьть» (ПсФ: л. 5).

Данная лексема, имеющая общеславянское распространение, относится к словам с неясной и спорной этимологией без индоевропейских соответствий, поэтому считается праславянской инновацией (см. BORYŚ 2005: 165). Она возводится к праслав. *glupъ $(j b)$ 'неразумный, глупый, тупой; дурацкий', 'безумный, шальной', 'неопытный, неискушенный', 'полностью затемненный', самым вероятным объяснением происхождения которого нам представляется его родство с праслав. *gluchb в связи с близостью ряда значений обеих форм, а также - с праслав. *glumъ 'шутка; насмешка', 'игра, забава, веселье', 'глупость, дурачество, блажь, дурь' (см. BORYś 2005: 165, ЭССЯ 7: 146-147, 147-148, 151-152). В таком случае *glupъ(jъ) является экспрессив- 
ным расширением с помощью лабиального элемента - $p$ - усеченной формы от *gluchb, которое, возможно, восходит к и.-е. *klous- 'слух', ‘слышать' с последующей веляризацией и.-е. $k$, а затем озвончением $k>g$ (ЭССЯ 7: 152, 146).

Т. А. Исаченко, занимавшаяся исследованием особенностей языка «Псалтыри 1683 г.» в переводе Аврамия Фирсова, в связи с рассматриваемым нами прилагательным отмечает: «Принципиальной модернизации подверглась лексическая система Псалтыри А. Фирсова - прежде всего, через последовательное преодоление старославянской лексики на путях усиления элементов просторечия, а также обращения к древнерусской лексике, стилистически противопоставленной старославянской: глупой вместо безуменъ» (ИсАчЕнкоЛисовАЯ-Лисовой 1987: 72).

Что касается бытования прилагательного глупьи 'stultus' в древнерусском языке, то наиболее раннее единичное его употребление зафиксировано в «Летописце Переяславля Суздальского» (под 1070 г.), известном в списке XV в. (СРезнЕВский 1: 522), тогда как безоумьныи в значении 'лишенный ума, сознания', 'безумный, безрассудный, неразумный', 'слабоумный, умалишенный' зарегистрировано в древнерусской письменности с XII по XIV в. 178 раз (СлДРЯ I: 145-146). ${ }^{5}$ Последующие фиксации анализируемого нами прилагательного в русском письменном языке относятся к XVI в., причем приходятся на тексты, близкие к разговорной речи: «Домострой» (список XVI в.), «Исторические песни XIII-XVI вв.» (списки XVIII-XX вв.), письма A. Курбского (список XVII в.), насыщенные полонизмами, а также на словари и разговорники, составленные иностранцами (СОРЯ 4: 96, СлРЯ ХІXVII вB. 4: 38). В русской лексикографии глупый впервые регистрируется в начале XVIII в. (ПоликАРПов 1704; л. 73 об.).

В тексте ПсФ доминирует прилагательное безумныи /безумнои - оно встречается 8 раз (см. ЦЕлуновА 2006: 428). Прилагательное глупьи / ллупои регистрируется в основном в паратексте ПсФ (см. выше, а также ПсФ: л. 20 об., 13: 2), и только один раз оно представлено непосредственно в тексте (ПсФ: л. 134, 98: 3). При этом показательно сопоставление глоссы 13: 2 к слову безумнои с оригиналами польских текстов Псалтыри, с которых осуществлялся перевод: глупои, или шаленои - Rzekt głupi и Mówił szalony (ЦЕлуновА 2006: 34). Из чего следует то, что использование глупыи / глупои в тексте ПсФ могло поддерживаться польскими текстами Псалтыри. Что касается анализируемых нами «Объяснения переводчика» и «Предисловия к читателю», то в этом случае переводчик, возможно, использовал ту лексему, которая доминировала в его лексиконе.

В письменности ВКЛ прилагательное глупьй, кглупылй 'дурны, неразумны, недарэчны' и глуnый, кглупый в значении существительного 'дурань' наблюдаются с первой четверти XVI в., причем в XVI-XVII вв. это слово

\footnotetext{
${ }^{5}$ Кроме того, в древнерусском языке в значении 'неразумный, глупый' с XII-XIII вв. засвидетельствовано синонимичное прилагательное боуии (СлДРЯ 1:323-324; см. ПолиКАРПОВ 1704: л. 12, л. 34 об., л. 73 об.).
} 
довольно часто употреблялось в документах и переводных текстах, язык которых насыщен полонизмами (ГСБМ 6: 301, СУМ 6: 225). ${ }^{6}$ Для белорусского языка судьба данной лексемы в указанных выше значениях далее XVII в. не прослеживается. Характер памятников, в которых глупый засвидетельствовано в письменности ВКЛ в XVI-XVII вв., непродолжительность его бытования в белорусском языке, а также то, что в одном из исторических словарей украинского языка глупій 'глупый' имеет помету «nл. głupi» (Тимченко 1: 175), может свидетельствовать о том, что по меньшей мере в письменность ВКЛ это слово могло попасть из польского, что подтверждается и хронологическими данными.

Так в старопольском głupi уже в XIV в. отмечается в значении 'głupi, tępy, niemądry, stultus, insǐpiens', а с начала XV - в значениях 'prostacki, rustīcus, lěvis' и ‘małej wartosci, błahy, vīlis' (SłStp 2: 433) и бытовало в польском языке на протяжении XVI-XVII вв. (SłP XVI 7: 434-436; SłPaska 1: 222), то есть имело непрерывную историю в интересующий нас период. При этом рассматриваемое прилагательное в XV-XVI вв. отличалось высокой частотностью употребления.

Сопоставление фактов из истории глупый в восточнославянских языках и głupi в польском, на наш взгляд, дает некоторые основания для того, чтобы рассматривать глуnый как заимствование из польского в письменность ВКЛ, но не дает пока достаточных оснований для предположения о заимствовании этого слова в русский язык из польского. ${ }^{7}$ Однако имеющаяся на данный момент информация позволяет, по нашему мнению, говорить о том, что польский язык, если и не был источником заимствования, то по меньшей мере мог стимулировать «возвращение» анализируемого прилагательного в активное употребление в русском письменном языке при посредничестве письменности ВКЛ в XVI-XVII вв.

Завершая обзор истории рассматриваемой лексемы в восточнославянских языках и польском, уточним наблюдение А. Баньковского о gtupi в этих языках: «...recesywne w płd. i wsch.-słow., żywotne w zach.-słow. W polskim barzdo ekspansywne, coraz częstsze w użyciu...» (BAŃKOwsKi 1: 439). Заметим, что из современных восточнославянских языков это замечание справедливо для белорусского языка, где гли́nы, но уже с другим значением 'глухой; недоступный, труднодоступный’ встречается только в диалектах (BORYŚ 2005: 165, ЭССЯ 6: 152), и украинского, где глу́nий в анализируемых значениях в словаре современного украинского языка сопровождается пометой «рідко» ${ }^{8}$ (ВТССУМ 2005: 246). А в русском языке лексема глупый в рассматриваемых

${ }^{6}$ В письменности ВКЛ с первой четверти XVI в. наблюдается также синонимичное прилагательное безумный в значениях 'нерозумний, нерозсудливий, безумний' и 'нерозумний, дурний’ (СУМ 2: 64, ГСБМ 1: 257-258).

${ }^{7}$ Нельзя исключать возможности появления в будущем дополнительной информации об употреблении этого слова в древнерусском языке, помимо случая, отмеченного И. И. СрезневСКИм (См. СРЕЗНЕВСКИЙ 1: 522).

${ }^{8}$ В XIX в. глупий еще входило в активный состав украинской лексики (ГРінчЕнко 1:291). 
значениях активно употребляется с XVI в. до настоящего времени (см. СлРЯ XVIII в. 5: 134, ДАль 1: 358, БАС 4: 170-171).

Господарство [1] c. Государство, царство, княжество: «Бывают нынђ в россииском господарствъ, несогласия, расколы, междоусобия» (ПсФ: л. 3 об.).

Данная лексема, известная в восточнославянских языках с XV в., является заимствованием из польского, где она представляет собой семантический латинизм (см. ЗолтАн 2002: 587-588, ЗолтАН 2014: 65-66, ГАРБуль 2014: 40), который получил новые семантические оттенки в актовом языке ВКЛ (см. ТАМАНЬ 1960: 112, ИСАЧЕНКО-ЛИСОВАЯ 1984: 254). В ПИсьмеННОстИ ВКЛ господарство в интересующем нас значении регистрируется со второй половины XV - первой четверти XVI в. (ССМ 1: 254, ГСБМ 7: 104, СУМ 7: 50). В Московской Руси господарство 'государство, царство, княжество' распространилось благодаря несомненному влиянию письменности ВКЛ (ЗоЛТАН 2014: 64).

Естли [4] союз условный (в придаточном условном предложении). В том случае, когда; если: «А естли им кто от... ученых людеи, учнет от таковаго злаго... дъла возбранят... и они собрався во едину храмину... сами сожигаются» (ПсФ: л. 4). «Такожде естли кто хощет увъдати неизреченную премудрость его» (ПсФ: л. 6). «Ты же о любезныи читателю, естли восхощеш... молитися... ты сыскав... псалмы молитвенныя, и читаи их» (ПсФ: л. 7). «Естли будешъ ихъ с разумом, и неспьшно читать, всъ сии псалмы самъ истинно познаеш, и их разбереш» (ПсФ: л. 7 об.).

Отнесение рассматриваемой лексемы к разряду полонизмов в русском языке достаточно убедительно обосновано в ряде исследований (ВиногРАдов 1999: 156, КосНмаN 1975: 75, см. также ИСАЧЕНКО-ЛИСОВАЯ-ЛИСОВОЙ 1987: 79, ЦЕлунова 2006: 103-104, WіткоWsкi 2006: 50, ГАРБУль 2014: 49). В русском письменном языке этот союз спорадически фиксируется уже в XVI в. (КоснмаN 1975: 75), более широкое распространение он получает с первой половины XVII в. (ГАрБуль 2014: 49). В письменности ВКЛ эта лексема известна со второй половины XV - начала XVI в. (ССМ 1: 350, ГСБМ 9: 227, СУМ 9: 101). Хронологические данные позволяют говорить о том, что проникновению естли (естьли) в русский письменный язык XVI-XVII вв. мог способствовать актовый язык и ВКЛ и «простая мова».

Инструменть (Иструменть) $[3]^{9}$ м. Прибор для извлечения музыкальных звуков: «Тамо разумъи едино... играние иструмента, кромђ гласа человЊческаго» (ПсФ: л. 8). «Тамо люди зачинали, а на иструментах приигрывано» (ПсФ: л. 8). «Тамо на иструментах зачинали, а люди припьвали» (ПсФ: л. 8).

${ }^{9}$ В тексте ПсФ эта лексема представлена шесть раз и встречается как в форме инструментъ, так и в форме иструментъ (см. ЦЕлуновА 2006: 490). 
В русский письменный язык XVII-XVIII вв. это слово, восходящее к латинскому instrūmentum 'орудие, снаряд, инструмент', в разных формах и различных значениях, в том числе и в интересующем нас, проникало разными путями: во второй половине XVII в. с ударением на предпоследнем слоге в формах инструменть, иструменть ${ }^{10}$ - из польского, а с ударением на последнем слоге в начале XVIII в. - из немецкого языка (Instrument) (ФАСмЕР 2: 135, ЭСлРЯ 7: 89, ИСАЧЕНКО-ЛиСОВАЯ 1984: 253, СлРЯ ХІ-XVII вВ. 6: 246, СлРЯ XVIII в. 9: 102, WiткоWSкі 2006: 66).

В актовом языке ВКЛ и текстах на «простой мове» инструменть, иструментъ как в рассматриваемом нами, так и в других значениях известно со второй половины XVI - начала XVII в. и считается заимствованием из латыни через польское и немецкое посредничество (БулыкА 1972: 129, БулыкА 1980: 187, ЕСУМ 2: 309, ЭСБМ 3: 390, ГСБМ 14: 128, СУМ 13: 147).

Сопоставление хронологических данных о появлении инструментъ, иструменть в русских письменных источниках и письменности ВКЛ позволяет, на наш взгляд, предполагать посредничество последней при заимствовании анализируемой лексемы в русский язык.

Мњрность [1] ж. Умеренность, воздержанность; мера: «Здъ смђшливыи, и веселыи, познаетъ, какову имать мърность сохранить во смЂянии, и веселии своем» (ПсФ: л. 6).

Данное существительное, являющееся внутриславянским дериватом, по мнению целого ряда исследователей, в восточнославянские языки было заимствовано из Польского (см. КОсНМАN 1975: 85-86, ИСАЧЕНКО-ЛИСОВАЯЛисовой 1987: 82, 96, ЦЕлУНОвА 2006: 124, WiтKOWSKI 2006: 107, ГАРБУЛЬ 2014: 87).

В русской письменности мърность впервые зарегистрировано в сочинениях А. Курбского, а также в тексте памятника «Назиратель», переведенного с польского языка (СлРЯ XI-XVII вв. 9: 103, КоснмаN 1975: 85). В письменных источниках ВКЛ это слово фиксируется с первой четверти XVI в. и первоначально именно в интересующем нас значении (ГСБМ 17: 351). Таким образом, письменность ВКЛ могла выступать в роли посредника при заимствовании лексемы $м$ ърность в русский письменный язык в последней четверти XVI в.

Набытие [1] c. Приобретение, получение чего-л.: «Всякаго блага набытие бывает, от читания слова божия с разумом» (ПсФ: л. 5 об.).

Это существительное представляет собой суффиксальное отглагольное образование от приставочного глагола праслав. *na-byti 'достигнуть, добиться

${ }^{10}$ Оформление этого слова, в котором оно встретилось в «Предисловии к читателю», по замечанию Т. А. Исаченко, показывает, как А. Фирсов упрощает комплексы «гласный + носовой» в заимствованиях из латыни в соответствии с нормами передачи польских носовых (ИСАЧЕНКО 1984: 252). 
чего-л., 'получить что-л.', 'завоевать, захватить что-л.', производного от имеющего общеславянское распространение и точные соответствия в балтийских и других индоевропейских языках праслав. *byti 'быть, существовать; жить', 'присутствовать, пребывать, находиться', 'стать, случиться, совершиться', восходящего к и.-е. имени *bhüti-s с глагольной основой аориста и в целом - прошедшего времени $* b^{h} \bar{u}$-[:* $\left.b^{h} e u(\partial)-\right]$ с первоначальным значением 'пухнуть, разбухать', 'расти, произрастать; созревать', затем - 'становиться; происходить, случаться', ‘быть, существовать' (см. BRÜCKNER 1974: 52, Boryś 2005: 48, 346, ФАСмер 1: 260, ЧЕРных I: 129, ЭССЯ 3: 155, ЭССЯ $21: 220)$. В этимологическом словаре украинского языка отмечается, что мотивирующий набытие глагол набыти (укр. набути) имеет распространение в основном в западнославянских языках, а в украинском и белорусском языках он, очевидно, является заимствованием из польского (ЕСУМ 4: 12, см. также BAŃKOWSKI 2: 239).

Т. А. Исаченко, исследовавшая язык ПсФ, относит набытие к полонизмам, однако не сопровождает свое мнение достаточной аргументацией (см. ИСАЧЕНКО 1984: 253, ИСАЧЕНКО 1987: 82, 96). На наш вЗГляД, это утверждение нуждается в дополнительной верификации с учетом новейших данных исторической лексикографии западнославянских и восточнославянских языков.

В русских письменных источниках данная лексема впервые отмечается в XVII в. и, по имеющимся на данный момент сведениям, в этом столетии она представлена всего двумя фиксациями: в ПсФ (см. выше) и в «Словаре западно-русском (славяно-латинском)» (СлРЯ XI-XVII вв. 10: 24). Далее XVII в. история существительного набытие для русского языка не прослеживается.

В старопольском языке nabycie 'osiągnięcie czego, uzyskanie czego' известно с середины XV в. и с тех пор на протяжении уже пяти с половиной столетий активно употребляется в польском языке (SłStp 5: 20, SłP XVI 15: 389, SłPaska 1: 456, Linde 3: 205, KarŁowicz 3: 15, SłJP 4: 968).

В письменности ВКЛ набытье, набыте, набытие, набытя в значении 'усё купленае, прыдбанае; маёмасць, набытак' и в интересующем нас значении наблюдается со второй половины XV в. и бытовало на протяжении XVIXVII вв. (ГСБМ 18: 306, ССМ 2: 10, Тимченко 1: 448). Примечательно, что в исторических словарях украинского языка эта лексема снабжена пометами «стч.», «стп.» и «пл.», которые указывают на ее происхождение (CСM 2: 10, Тимченко 1: 448). Набыцие 'пріобрђтеніе' регистрируется в словаре, отражающем белорусский язык XVIII-XIX вв. (Носович 1870: 299), набыцицё ‘то же’ употребляется и в современном белорусском языке (ТСБМ 3: 210). В анализируемом нами значении набуття представлено и в словарях, фиксирующих украинский язык ХІХ - начала ХХІ в. (ГРІнченко 2: 466, ВТССУМ 2005: 702).

Итак, характер памятников, в которых набытие было зарегистрировано в XVII в., а также его история достаточно убедительно свидетельствуют о неисконности этого слова в русском языке. При этом информация об истории рассматриваемой лексемы в польском языке и письменности ВКЛ позволяет 
сделать вывод о заимствовании ее в русский письменный язык XVII в. из польского при посредничестве актового языка ВКЛ и / или «простой мовы».

Что касается источника этого слова в польском языке, то не исключено, что в старопольский оно попало из старочешского, где nabytie «k nabyti ‘čeho nabytí, získání'» было известно с третьей четверти XIV в. (StčS1 3: 25, см. также CCM 2: 10).

Неотмњнно [2] нареч. Постоянно, неизменно, непреложно: «А сия святая книга... на всякии день, во весь год читаема бывает, во всякую церковную службу, неотмънно» (ПсФ: л. 5 об.). «Сего ради на всякии день читают ея во церквђ божии, неотмънно во весь год» (ПсФ: л. 6 об.).

Анализируемое наречие, вероятнее всего, представляет собой суффиксальное производное от префиксального прилагательного праслав. *otъmе̌$n b n z j b$, известного в западно- и восточнославянских языках и образованного от имеющих общеславянские распространения приставочного глагола *otbměniti 'отменять; заменять' или существительного *otъ-те̌na 'отмена; замена', восходящих к праслав. *mе̌nа 'изменение, перемена', 'мена, обмен' < и.-е. основа *mei-n-o: *moi-n-o от корня *mei-: *moi- 'менять, обменивать; меняться' с расширителем -n- (BoRYŚ 2005: 324, ЧЕРных 1: 522, ЭССЯ 18: 171-172, 173-174, ЭССЯ 37: 181-183, 184-185, 187-188).

Неотмънно регистрируется в русской деловой письменности с 60-70-х годов XVII в., причем первоначально в дипломатической корреспонденции (СлРЯ XI-XVII вв. 11: 205). В словаре, отражающем русский язык XVIII в., эта лексема в значении 'непременно, обязательно; неизменно, постоянно' снабжена пометой «слово, выходящее из употребления» (СлРЯ XVIII в. 14: 250). В значении 'непременно, обязательно' это наречие еще регистрируется в лексикографических источниках русского языка первой четверти XIX в. (САР 3: 1343). В словаре, фиксирующем современный русский язык, неотменно 'непременно, обязательно' снабжено пометой «устар.» (БАС 12: 127). Тогда как в диалектах северных и западных областей (губерний) России анализируемая лексема в указанном выше значении, а в говорах Урала и в значении 'вполне, подходяще' отмечалась и во второй половине XIX-XX вв. (СРНГ 21: 104-105).

Учитывая характер памятников, на которые приходятся наиболее ранние фиксации неотмънно, в том числе и исследуемый нами текст, а также то, что мотивирующее наречие прилагательное неотмънный впервые засвидетельствовано более чем на десятилетие позже и в XVII в. представлено единичным употреблением (СлРЯ XI-XVII вв. 11: 205), можно предположить неисконность анализируемой лексемы для русского языка. Возможным ее источником в русском письменном языке второй половины XVII в. мог быть польский язык. В пользу этого предположения свидетельствует то, что семантическим полонизмом в русской письменности XVII в. является прилагательное отмънныц̆ в значении 'изменчивый, непостоянный' (ГАРБУль 2009: 222-223). 
В польских источниках nieodmiennie 'bez zmian, zawsze tak samo, niezmiennie, stale; nieprzerwanie' засвидетельствовано с начала XVI в. (SłP XVI 17: 435). В этом значении рассматриваемое наречие бытовало в польском языке XVII-XIX вв. (SłPaska 1: 495, KARŁOWICZ 3: 301), и в словаре современного польского языка nieodmiennie регистрируется в значении ' $\mathrm{w}$ ten sam sposób, tak samo, bez żadnych zmian; niezmiennie, jednakowo' (SłJP 5: 120).

В письменности ВКЛ анализируемое наречие в форме неотменне в значении 'нязменна, пастаянна; заўсёды' представлено единичным случаем уже в конце XV в. в сильно полонизированном документе, более широкое распространение в приведенной выше форме оно получает в актовом языке ВКЛ и текстах на «простой мове» с середины XVI в., а в форме неотменно 'то же' с начала XVII в. (ГСБМ 20: 190-191). Примечательно, что в памятниках ВКЛ наречие встречается более чем на четыре десятилетия раньше мотивирующего его прилагательного ${ }^{11}$ (см. ГСБМ 20: 191), а в историческом словаре украинского языка неотмънне сопровождается пометой «пл. nieodmiennie», которая указывает на его происхождение (Тимченко 1: 492). Основываясь на приведенной информации, мы считаем, что в письменность ВКЛ анализируемое наречие было заимствовано из польского. Этому не противоречит то, что в актовом языке ВКЛ оно зарегистрировано несколько раньше, чем в польском. Венгерский славист А. Золтан замечает, что это не исключает возможности существования какого-либо слова в старопольском языке намного раньше его фиксации в памятниках, объясняя такие случаи доминированием латыни в письменности средневековой Польши (ЗолтАн 2014: 109).

В словарях, отражающих белорусский (неодмънно) и украинский (неодмінне и неодмінно) языки XVIII-XIX вв., анализируемое наречие представлено в значении 'непремънно' (Носович 1870: 333 , Тимченко 1: 492, ГРінченко 2: 552). В толковом словаре современного белорусского языка наречие вообще не регистрируется, а в словаре современного украинского языка находим его в следующих формах: невідмінно 'те саме, що неодмінно' с пометой «рідко», неодмінне 'неодмінно' с пометой «діал.» и неодмінно «присл. до неодмінний 'обов' язковий; постійний, незмінний'» (ВТССУМ 2005: 750, 769).

Если сопоставить приведенные выше данные о неотмънне, неотмънно, неотменне, неотменно в восточнославянских языках и nieodmiennie в польском, то, на наш взгляд, есть достаточные основания, чтобы считать эту лексему в первых лексическим полонизмом, который в русский письменный язык второй половины XVII в. проник, очевидно, благодаря посредничеству актового языка ВКЛ и «простой мовы».

Обыклой [1] прил. Обыкновенный, обычный, обыденный; простой: «Преведена сия святая... книга... на нашъ простои, обыклои, словенскои языкъ» (ПсФ: л. 1).

${ }^{11}$ При этом отменный 'зменлівы, непастаянны; часовы, недаўгавечны’ наблюдается уже с конца 60-х гг. XVI в., а мотивированное им неотменный 'нязменны, пастаянны' - с середины 30-х гг. того же столетия (ГСБМ 23: 149, ГСБМ 20: 191). 
Это прилагательное представляет собой отглагольное образование от имеющего общеславянское распространение праслав. *ob-vykn ti 'привыкнуть' или *ob-vykti 'то же' (сложение *ob- и слабо представленного в свободном виде глагола *vykti 'приучать к чему-л.; приобретать привычку, навык, умение, опыт; учиться, обучаться чему-л.', соотносительного с *vyknoti), где *vyknoti: *vykti (с протетическим v) связано чередованием гласных с праслав. *učiti 'учить чему-л., прививать навык, приучать к чему-л.' < и.-е. корень * euk- (:*ouk-): *ūk- 'приучаться; привыкать', 'доверять' (см. ФАСмеР 1: 368, ФACMEP 4: 179-180, ЧЕРныX 2: 297, ЭССЯ 31: 116-117, REJZEK 2001: 421, BORYŚ 2005: 662).

Наиболее раннее употребление обыклый отмечено в дипломатическом документе 1614 г., отражающем контакты Московского государства с Польшей и ВКЛ, более широкое распространение это прилагательное получает со второй половины XVII в. и встречается в основном в деловой письменности (СлРЯ XI-XVII вв. 12: 211). В историческом словаре, регистрирующем русский язык XVIII в., обылкльй в интересующем нас значении снабжено пометой «выходящее из употребления», а иллюстративный материал ограничивается первой четвертью этого столетия (СлРЯ XVIII в. 16: 141). В лексикографических источниках XIX в. обыклый представлено только в значении 'пріучившїйся, привычку сдълавшій' (САР 4: 161, ДАль 2: 637). В словаре современного русского литературного языка обыклый 'ставший обычным, обыкновенный; привычный’ имеет пометы «устар.» и «обл.» (БАС 13: 434). В указанном выше, а также в значении 'ручной (о животном, птице)' это прилагательное в XIX-XX вв. отмечалось в говорах северных и западных областей (губерний) России (СРНГ 22: 287).

История лексемы обыклый в русском языке наводит на мысль о возможной ее неисконности, а поскольку в XVII в. бо́льшая часть внутриславянских дериватов проникала из польского, то не исключено, что и это слово является полонизмом. Наше предположение подтверждается данными хронологии. Так, в старопольской письменности с конца 20-х гг. XV в. известно obwykty 'zwyczajny, normalny, pospolity', a c 40-х гг. того же столетия фиксируется и obykty 'zwykły, taki jak zawsze, normalny' (SłStp 5: 394, 399-400). При этом в старопольском языке это прилагательное, возможно, представляет собой богемизм, потому что в старочешском языке obyklý 'obyčejný, prostý' засвидетельствовано уже в конце XIV в. (StčSl 4: 236).

Obwykty, obykty еще регистрируются в реестре словаря польского языка XVI в., но без иллюстраций (SłP XVI 19: 491, 516), a nieobwykty 'nieprzywykły, nie przyzwyczajony (czemu)' представлено в этом источнике одним примером под 1534 г. (SłP XVII). Далее XVI в. история этих лексем для польского языка пока не прослеживается.

В письменности ВКЛ обыклый 'звычайны' отмечено один раз в источнике конца XVI в., насыщенном полонизмами (ГСБМ 21: 322). Анализируемое прилагательное в значении 'обыкновенный' фиксируется в словаре, отражающем белорусский язык XVIII-XIX вв. (Носович 1870: 356), и в совре- 
менном белорусском языке абыкль 'заўсёдны, звыклы' входит в активный лексический состав языка (ТСБМ 1: 90). В украинском языке эта лексема не представлена.

Исходя из приведенной выше информации, на наш взгляд, есть определенные основания предполагать, что обыклый могло попасть в восточнославянские языки из польского. При этом проникновению его в русский письменный язык XVII в., очевидно, способствовала «простая мова».

Отворенный [1] прич. страд. прош. вр. в знач. прил., перен. Открытый, свободный, доступный для кого-л., чего-л.: «В неи отворенная школа учения того» (ПсФ: л. 6).

Анализируемая лексема представляет собой страдательное причастие прошедшего времени от имеющего общеславянское распространение и соответствия в балтийских и других индоевропейских языках глагола, восходящего к праслав. *otvoriti 'вызвать открытие, раскрытие, разжатие, размыкание чего-л.', каузативу к праслав. приставочному *ot-verti, 1 л. ед. ч. *ot-vbr' $Q$ 'открыть, раскрыть, растворить; разжать, разомкнуть' (с перегласовкой e/o) < и.-е. база *uer-t- (: *ur-t-) 'вертеть; поворачивать', корень *uеr- 'закрывать, заПирать' (см. ПРЕОБРАЖЕНСКИЙ 1: 77-78, ФАСМЕР 1: 301, ФАСМЕР 3: 169-170, ЧерныХ 1: 144, BORYŚ 2005: 404).

В русской письменности наиболее ранние случаи употребления прилагательного отвореный и оттвореный в составе устойчивых сочетаний относятся к концу XV-XVI вв.: оттвореная грамота (листь) 'документ на право беспрепятственного проезда’ регистрируется в дипломатических документах, отражающих контакты Московского государства с Польшей и ВКЛ (1496 г.), а также со Священной Римской империей (1517 г.), отвореная земля 'вспаханная земля, не целина' отмечается в последней четверти XVI в. в переводном с польского языка источнике «Назиратель» (СлРЯ XI-XVII вв. 13: 206). Страдательное причастие прошедшего времени отвореный, оттвореный в переносном употреблении 'открытый, свободный, доступный для кого-л., чего-л.' в значении прилагательного впервые регистрируется также в тексте «Назиратель», а мотивирующий его глагол в соответствующем значении впервые отмечен в «Геннадиевской библии» конца XV в., но примеры употребления глагола в этом значении в XVI-XVII вв. в историческом словаре не приводятся (СлРЯ XI-XVII вв. 13: 207). Глагол отворить и причастие отворе́нный, отворе́ный в интересующем нас переносном значении 'дать доступ куда-л.; сделать что-л. доступным' регистрировались в русском письменном языке на протяжении всего XVIII в. (СлРЯ XVIII в. 17: 210). В лексикографическом источнике первой четверти XIX в. представлено прилагательное отво́ренный в прямом значении 'отверстый, растворенный' (САР 4: $490,491)$. И в другом словаре этого столетия как глагол отворить, так и образованное от него страдательное причастие прошедшего времени фиксируются только в прямом значении (ДАль 2: 716). В современном русском языке 
эти лексемы (отворить, отво́ренныцй и отворённый «устар.») также употребляются лишь в прямом значении (БАС 14: 376-377).

История глагола отворити и производных от него причастия и прилагательного в интересующем нас переносном значении наводит на мысль о том, что глагол в данном значении, возможно, является семантическим полонизмом, ${ }^{12}$ а причастие в значении прилагательного - лексическим полонизмом в русском языке. Так, в старопольском языке и глагол otworzyć, и прилагательное otworzony известны с XIV в., прилагательное в значении 'jawny, publiczny' - с 90-х гг. XIV в., в значении 'piękny, pulchĕr (?)' ${ }^{13}$ - с начала второй четверти XV в., в устойчивых сочетаниях: otworzona rana - с конца 10-х гг. $\mathrm{XV}$ в., otworzony czas, rok, otworzone dni - с середины того же столетия (SłStp 5: 697-698). В интересующем нас переносном значении глагол otworzyć и причастие otworzony засвидетельствованы в первой половине XV в. (StStp 5: 699). И в XVI в. причастие otworzony регистрировалось в памятниках польской письменности в значениях 'dostępny komu, czemu', 'odkryty, jawny', 'udostępniony komu' (SłP XVI 22: 352, 353, 354-355). В словаре, регистрирующем польский язык XVII в., глагол otworzyć представлен только в прямом значении, а причастие otworzony в значении 'o instytucji, organizacji: taki, który rozpoczął działalność’ (SłP XVII). Таким образом, далеe XVI в. история otworzony в интересующем нас переносном значении для польского языка пока не прослеживается, хотя в других переносных значениях оно в составе устойчивых сочетаний и фразеологизмов до сих пор входит в активный состав польской лексики (SłJP 5: 1226-1227).

В актовом языке ВКЛ первая фиксация причастия отвореный, отворенный, оттворенылй относится к 1420 г., а мотивирующий его глагол отворити засвидетельствован только со второй половины XV в., причем обе лексемы употреблены в переносных значениях в документах, насыщенных полонизмами (ГСБМ 23: 46, 48, ССМ 2: 101). В интересующем нас переносном значении 'рабіць адкрытым, даступным для каго-н., чаго-н.' и в значении 'адкрываць; паведамляць што-н. важнае, таемнае' глагол отворити и мотивированное им причастие, в том числе и в значении прилагательного, наблюдались сначала в деловой письменности ВКЛ (с конца XV - начала XVI в.), а позднее - и в текстах на «простой мове» до середины 50-х гг. XVII в. (ГСБМ 23: 45, 48, ССМ 2: 101). При этом следует отметить, что язык памятников, в которых они зафиксированы, испытал заметное влияние польского. Далее середины XVII в. судьба как глагола отворити, так и производных от него причастия и прилагательного ни в письменности ВКЛ, ни в белорусском и украинском языках не прослеживается.

${ }^{12}$ В прямом значении 'отворить, открыть' этот глагол в древнерусском языке отмечается с ХІІІ в. (СлДРЯ 6: 203-204).

13 Это значение в словаре старопольского языка представлено единственной иллюстрацией, и далее XV в. история его пока не прослеживается. Не исключено, что в ПсФ отворенный может иметь это значение (?). В таком случае следует говорить о семантическом заимствовании из польского. 
Приведенные выше факты из истории отворити, отворенный, отвореный в русском языке и в письменности ВКЛ, а также otworzyć, otworzony в польском языке дают, по нашему мнению, определенные основания для того, чтобы считать эти лексемы в письменности ВКЛ лексическими полонизмами. ${ }^{14}$ В русском письменном языке отворити 'сделать открытым, свободным, доступным для кого-л., чего-л.', возможно, является семантическим заимствованием из польского, а мотивированное им причастие в значении прилагательного в соответствующем значении - лексическим полонизмом, который был заимствован, вероятнее всего, благодаря посредничеству актового языка ВКЛ и «простой мовы».

Побуждение [1] с. Действие по знач. глаг. побудить сов., побуждать несов. 'склонить, побудить к какому-л. действию': «Со читания слова божия, с разумом, приходить человЊку... побуждение к покаянию» (ПсФ: л. 5 об.).

Это существительное представляет собой суффиксальное производное от префиксального глагола, который восходит к имеющему общеславянское распространение и соответствия в балтийских и других индоевропейских языках праслав. *buditi, 1 л. ед. ч. *budjo 'выводить из состояния сна; прерывать чей-л. сон', родственному праслав. *bъděti 'не спать, бодрствовать' (в морфо-

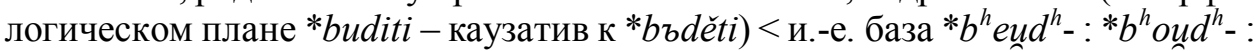
* $b^{h} \breve{u} d^{h}$ - ‘бодрствовать, не спать', 'быть внимательным', 'следить, наблюдать' (ФАСмеР 1: 140-141, 230; Черных 1: 117, ЭССЯ 3: 76-77, 109; Borý́ 2005: 45).

До сих пор считалось, что анализируемая лексема появилась в русском письменном языке в конце 20-х - начале 30-х гг. XVIII в. именно в указанном выше значении (СлРЯ XVIII в. 20: 85). Наши данные позволяют удревнить хронологию этой лексемы в русском языке почти на полстолетия. Таким образом, существительное побуждение в интересующем нас значении входит в лексический запас русского языка на протяжении уже более трех столетий (САР 4: 1158, ДАль 3: 138, ССРЛЯ 10: 52-53).

Учитывая то, что мотивирующий рассматриваемое существительное глагол побудити 'склонить, побудить к какому-л. действию' впервые регистрируется в переводном с польского языка тексте (см. СлРЯ XI-XVII вв. 15: 135), а однокоренные существительные побудка 'то, что побуждает к чему-л., побуждение' и побудитель 'тот, кто побуждает, склоняет, подстрекает к чему-л., поощряет что-л.' являются полонизмами (см. WITKOWSKI 2006: 150, ГАРБуль 2014: 118), мы склонны предполагать, что источником лексемы побуждение в русском языке также был польский язык. В пользу этого предположения может свидетельствовать и то, что А. Фирсов в процессе перевода активно пользовался польскими текстами Псалтыри (ЦЕЛуновА 2006: 8), что могло сказаться и на околотекстовом окружении перевода.

${ }^{14}$ Примечательно, что в одном из исторических словарей украинского языка глагол omворити, представленный в переносном значении, снабжен пометой «nл. otworzyć» (Тимченко 2: 62). 
В старопольском языке pobudzenie 'podnieta, zachęta, incǐtāmentum' известно с 80-х гг. XV в. (SłStp 6: 197), а с XVI в. и вплоть до настоящего времени эта лексема входит в активный лексический состав польского языка (SłP XVI 25: 137-138, LINDE 4: 182, KARŁOWICZ 4: 293, SłJP 6: 551).

В актовом языке ВКЛ, в документе по сношениям с Польшей конца 40-х гг. XV в., регистрируется единичное употребление имперфектива побужати 'спонукати, спонукивати (кого)' (CCM 2: 158). C конца XV в. в письменности ВКЛ фиксируется перфектив побудити, причем первоначально в переносном значении 'схіліць, падбухторыць (да чаго-н.), падбіць, натхнуць (на што-н.) ' в переводном с польского языка тексте (ГСБМ 24: 440-441). Более широкое распространение побужати, побудити в интересующем нас значении получают в актовом языке ВКЛ и текстах на «простой мове» уже в XVI в. (ГСБМ 24: 441, 444). Наиболее ранняя регистрация существительного побуженье в рассматриваемом нами значении обнаружена в памятнике «Аповесць аб трох каралях-валхвах», который переведен с польского языка в конце XV века; более широко эта лексема представлена в деловой письменности ВКЛ и в «простой мове» со второй половины XVI в. (ГСБМ 24: 445, Тимченко 2: 116). В белорусском языке XVIII-XIX вв. побужа́нне засвидетельствовано в значении 'понужденіе, понуканіе' (Носович 1870: 423). В толковом словаре современного белорусского языка пабуджэнне представлено в значении «дзеянне паводле знач. дзеясл. пабуджаџь 'выклікаць жаданне рабіць што-н.; прымушаць да чаго-н.' » с пометой «кніжн.» и в значении 'жаданне, патрэба зрабіць што-н.' (ТСБМ 3: 466). В словаре современного украинского языка побу́дження 'бажання або намір зробити що-н.' снабжено пометой «діал.» (ВТССУМ 2005: 991).

Сопоставление приведенной выше информации позволяет, на наш взгляд, сделать вывод о том, что в восточнославянских языках анализируемое существительное, видимо, является заимствованием из польского. При этом в русский письменный язык второй половины XVII в. оно могло попасть благодаря посредничеству письменности ВКЛ.

Приигрывати [1] несов. Аккомпанировать, подыгрывать на музыкальном (-ых) инструменте (-ax): «А идђ же псалом пъсни, тамо люди зачинали, а на иструментах приигрывано» (ПсФ: л. 8).

Анализируемая лексема представляет собой префиксальный глагол многократного подвида, восходящий к имеющему общеславянское распространение праслав. *jbgrati, 1 л. ед. ч. *jbgrajo 'участвовать в (обрядовых) играх', 'плясать; прыгать, скакать', отыменному производному от *jbgra 'обрядовая игра с танцами; пение с пляской', образованному на праславянской почве от и.-е. корня *iag-: ig- (может быть, *ieg-: *ig-), возможно, *aig-: *eig- 'совершать резкие движения; размахивать, махать; трясти', 'шевелить (ся)', 'колебать(ся)' с суффиксом *-r-, первоначально, видимо, обозначавшему название действия (см. ФАСМЕР 2: 116, ЭССЯ 8: 208-210, 210-211; ЧЕРных 1: 334-335, BORYŚ 2005: 175-176, 176-177). 
Рассматриваемый глагол в интересующем нас значении не удалось обнаружить ни в одном лексикографическом источнике русского языка. Два случая употребления прии́грывать, но в ином значении 'петь песни в честь кого-л.’ были зарегистрированы в говоре Мосальского уезда Калужской губернии в первой четверти ХХ в. (СРНГ 31: 231). Таким образом, использованный А. Фирсовым в «Предисловии к читателю» глагол приигрывати 'аккомпанировать, подыгрывать на музыкальном (-ых) инструменте (-ax)', следует, видимо, считать окказионализмом в русском письменном языке XVII в.

В памятниках польской письменности przygrawać в значении 'grać dla kogoś' известно с середины XVI в., а в значении 'akompaniować, wtórować' с 80-90-х гг. того же столетия (SłP XVI 33: 217-218). Позднее, с первой четверти XVII в., этот глагол регистрируется в форме przygrywać 'towarzyszyć komu, czemu na instrumencie muzycznym, grać przy różnego rodzaju okazjach (np. do tańca); wtórować, akompaniować', в которой он активно употребляется до настоящего времени (LINDE 4: 636, KARŁOWICZ 5: 291, SłJP 7: 526).

В письменности ВКЛ выявить этот глагол нам не удалось. В словарях, отражающих украинский язык XIX-XXI вв., представлен глагол приграва́ти 'акомпанувати' (Грінченко 3: 413, ВТССУМ 2005: 1114). В белорусском языке этот глагол не засвидетельствован.

Подводя итог анализу истории глагола приигрывать в восточнославянских языках можно констатировать, что в эти языки он, вероятнее всего, попал из польского.

Читание [7] c. Действие по знач. глаг. читать 'воспринимать что-л. написанное или напечатанное буквами или другими письменными знаками, произнося вслух или воспроизводя про себя; знакомиться с содержанием чего-л. написанного или напечатанного': «От читания слова божия... множится вђра» (ПсФ: л. 5). «Вђра от читания слова божия бывает» (ПсФ: л. 5). «Со читания слова божия... приходитъ... познание закона божия» (ПсФ: л. 5 об.). «Всякаго блага набытие бывает, от читания слова божия с разумом...» (ПсФ: л. 5 об.). «Токмо продолжение времене в том читании бываеть... А ползы и услаждения себђ от того читания, не приемлем...» (ПсФ: л. 6 об.). «И к таковому своему читанию, приложи свои здравои разумъ» (ПсФ: л. 8 об.).

Рассматриваемое существительное представляет собой суффиксальное образование от имеющего общеславянское распространение глагола, восходящего к праслав. *čitati, 1 л. ед. ч. *čitajo, итеративу-дуративу к праслав. *čisti, 1 л. ед. ч. *čbto 'считать, производить подсчеты', 'различать, распознавать знаки; замечать', 'понимать', 'думать, полагать, считать; судить', 'учитывать что-л.', и.-е. базой которых является * $(s) k^{u} e i t-:$ * $(s) k^{u} \breve{\imath} t$ - 'замечать', 'думать; считать, полагать', ‘уважать, почитать' (см. ФАСмЕР 4: 367, 374-375; Черных 2: 391-392, ЭССЯ 4: 119, 123; BoRYś 2005: 105).

В русской лексикографии эта лексема в значении 'lectio, rĕcĭtātio' отмечается с начала XVIII в. (ПоликАрпов 1704: л. 162). На данный момент обнаруженное нами употребление читание А. Фирсовым можно считать одной 
из наиболее ранних фиксаций этого слова в русском письменном языке. Существительное чита́ние 'дЂйствіе читающего' представлено в словаре первой четверти XIX в. и у Вл. Даля (САР 6: 1305, ДАль 4: 608). В «Словаре современного русского литературного языка» чита́нье уже снабжено пометами «устар.» и «разг.» (ССРЛЯ 17: 1085).

Польский славист В. Витковский относит читание к полонизмам (см. WitKOWSKI 2006: 234), но при этом ничем не подкрепляет свое мнение, поэтому обратимся к истории этой лексемы в польском языке. В польских письменных источниках czytanie 'rozpoznawanie i łączenie liter w wyrazy; zapoznawanie się z treśią pisaną; lectio (litterārum)’ известно с середины 30-х гг. XVI в. и уже в этом столетии вошло в активное употребление (SłP XVI 4: 367-368) и бытует в польском языке на протяжении почти пяти столетий вплоть до настоящего времени (SłP XVII, LinDE 1: 400, KARŁowICZ 1: 415, SłJP 1: 1195).

В письменности ВКЛ читание, читанне, читанье, чытание, чытанье в интересующем нас значении 'чытанне' засвидетельствовано с середины 90-х гг. XVI в., а с середины XVII в. это существительное отмечается также в значениях 'уменне усспрымаць, разумець напісанае' и 'тое, што чытаюць', причем в XVI-XVII вв. эта лексема во всех своих значениях фиксируется в деловых актах и текстах на «простой мове», язык которых в значительной степени насыщен полонизмами (ПГССЛ 2: 473). Существительное чита́ння 'чтеніе' регистрируется в словаре, отражающем украинский язык XIX в., и в словаре современного украинского языка (ГРІнченко 4: 465, ВТССУМ 2005: 1603). В словаре современного белорусского языка чыта́нне также представлено в интересующем нас значении (ТСБМ 5: 335).

Итак, приведенная выше информация, по нашему мнению, подтверждает предположение В. Витковского о заимствовании читание в русский язык из польского. В другие восточнославянские языки это существительное, вероятнее всего, проникло из того же источника. ${ }^{15}$ В таком случае письменность ВКЛ могла выступать в роли посредника при заимствовании читание в русский письменный язык XVII в.

Читатель [7] м. Тот, кто читает, кто занят чтением каких-л. произведений, к кому обращены произведения письменности: «Предисловие къ читателю» (ПсФ: л. 5). «Возлюбленныи читателю, уготоваи себе, ко прочитанию слова божия» (ПсФ: л. 5). «Ты же о любезныи читателю... сыскав в неи псалмы молитвенныя, и читаи их неспъшно» (ПсФ: л. 7). «ВБдаи убо и сие любезныи читателю, иже в сеи книгъ псалмы суть разныя» (ПсФ: л. 7 об.). «Сего ради потреба тебъ въдати любезныи читателю... тогда тамо разумьти играние иструмента» (ПсФ: л. 7 об.). «По надписанию их любезныи читателю разберешъ и, самъ увъдаешъ истинно» (ПсФ: л. 8). «Ты же любезныи читателю, в молитвђ своеи читаи псалмы молитвенныя» (ПсФ: л. 8 об.).

15 Учитывая то, что с последней четверти XV в. в письменности ВКЛ в значениях 'чытанне' и 'тое, што чытаюць' было известно существительное чтение, чтенье, синонимичное слову читание, читанье (ПГССЛ 2: 476). 
Лексема читатель является суффиксальным отглагольным производным (о происхождении глагола читать см. выше: анализ слова читание).

Согласно данным П. Я. Черных и «Словаря современного русского литературного языка», слово чита́тель впервые отмечается у П. Берынды (см. Черных 2: 392, ССРЛЯ 17: 1085-1086). Однако у П. Берынды оно представлено не в интересующем нас значении (БЕрындА 1627: л. 305), а в значении 'чтец' с отсылкой к слову клирикъ 'причетник, церковный слуга' (БЕРындА 1627: л. 97). В древнерусском языке лексема чьтьиьь, четьиь 'чтецъ (церковная должность)' наблюдается с ХІ в. (СРезневский 3: 1580, Черных 2: 392). В лексикографическом источнике начала XVIII в. чита́mель представлено уже и в интересующем нас значении 'lector, anagnostes' (ПоликАРПов 1704: л. 162). Причем в том же источнике регистрируется и слово чтецъ в значении 'lector' (ПоликАРПов 1704: л. 163), из чего следует, что по меньшей мере в XVII в. читатель и чтецъ были синонимами в интересующем нас значении, и не исключено, что последнее употреблялось в этом значении и в более раннее время. В словаре первой четверти XIX в. чита́тель фиксируется только в значении 'тотъ, кто занимается чтеніемъ чего', а чтеиъ - в значениях 'тотъ, кто опредъленъ къ чтенію чего (чтецъ церковный)' и 'кто ясно, внятно читать можеть (искусный въ чтеніи)' (САР 6: 1305, 1315). Таким же образом обе лексемы представлены и в словаре, отражающем русский язык XIX в. (ДАль 4: 608). В современном русском языке лексема читатель до сих пор употребляется в интересующем нас значении (ССРЛЯ 17: 1085). А что касается слова чтещ, то в «Словаре современного русского литературного языка» оно приводится в следующих значениях: 'тот, кто читает что-н. написанное, изданное' с пометами «устар.» и «разг.», 'тот, кто читает вслух для слушателей', 'тот, кто искусен в художественном чтении' и 'человек, читающий псалтырь по умершему’ (ССРЛЯ 17: 1112-1113).

Ряд обстоятельств: характер источника, в котором отмечена наиболее ранняя известная на данный момент фиксация существительного читатель в восточнославянских языках, а также то, что за пределами XVII в. эта лексема не засвидетельствована ни в белорусском, ни в украинском языках, наводит на мысль о возможной ее неисконности в этих языках.

Так, в польских памятниках письменности с 20-х гг. XVI в. наблюдаются синонимичные лексемы, выражающие интересующее нас значение: czciciel, ćciciel, tciciel 'czytelnik; lector; anagnostes, recitator' и czytelnik 'człowiek czytający; lector', которое с 60-х гг. того же столетия отмечается также в значениях 'człowiek odczytujący głośno tekst (innym), lector, anagnostes, recitator' и 'lektor, kleryk, mający drugie, niższe swięcenie kapłańskie, zajmujący się w kościele katolickim czytaniem w czasie nabożeństwa Pisma św. wiernym, dozorem nad księgami kościelnymi itp.' (SłP XVI 4: 110, 370-371; BAŃKOwsKi 1: 219, 243; ReCZeK 1968: 53). C 60-70-х гг. XVI в. в польских источниках засвидетельствовано также существительное $c z y t a c z$ в тех же значениях, что и приведенное выше czytelnik (SłP XVI 4: 361, BAŃKOWSKI 1: 243, RECZEK 1968: 59). История лексемы czciciel в польском языке ограничивается концом XVI в., 
лексема $c z y t a c z$ к XVII в. также выходит из активного употребления (LINDE 1: 358, 400; KARŁowICz 1: 414, 415), а czytelnik в указанных ранее значениях продолжало бытовать в польском языке и в XVII-XIX вв. (SłP XVII, LINDE 1: 400, KARŁowicz 1: 415). В настоящее время только слово czytelnik в интересующем нас значении ${ }^{16}$ входит в активный лексический состав польского языка (SłJP 1: 1196).

По данным исторического словаря белорусского языка, в памятниках ВКЛ читатель в значении 'чытач' впервые представлено в предисловии к «Лексікону славеноросскому и именъ тлькованію» (1653 г.) П. Берынды (ПГССЛ 2: 473), ранее в письменности ВКЛ засвидетельствованы синонимичные лексемы: читачь 'то же' - с 50-60-х гг. XVI в., а с 80-90-х гг. того же столетия - чительникъ, читольникъ 'то же', считающееся заимствованием из польского (ТимЧЕнко 2: 482, БулыкА 1972: 357, ПГССЛ 2: 473). Лексема чтецьъ фиксируется в письменных источниках ВКЛ со второй половины XVII в. только в значении 'ніжэйшы царкоўны чын' (ПГССЛ 2: 476). В словаре, регистрирующем украинский язык XIX в., находим чита́ч 'читатель' и чите́иь 'то же' (Грінченко 4: 465). В современном украинском языке в интересующем нас значении продолжает бытовать существительное чита́ч, слова чита́льник 'читач' и чите́ų 'то же' в толковом словаре снабжены пометой «заст.», а последнее - еще и пометой «розм.» (ВТССУМ 2005: 1603). В современном белорусском языке лексема чыла́ч употребляется в значении 'той, хто чытае якія-н. творы, да каго звернуты творы пісьменнасці', а чылта́льнік - в значении 'чалавек, які з высокім майстэрствам чытае творы мастацкай літаратуры; артыст, дэкламатар, які выступае з чытаннем’ (ТСБМ 5: 334, 335).

Сопоставление приведенной выше информации не позволяет говорить о заимствовании слова читатель как такового из польского в восточнославянские языки. Однако мы все-таки допускаем вероятность польского влияния в появлении этой лексемы в восточнославянских языках: лексема читаmель могла возникнуть в результате контаминации польского czciciel, возможно, известного в XVI в. и в письменности ВКЛ, и синонимичного ему $c z y t a c z$, наблюдавшемуся и в памятниках ВКЛ, где чытачъ встречается даже несколько раньше, чем в польском. Во всяком случае, на данный момент, учитывая недостаток информации об истории анализируемой лексемы в восточнославянских языках, данная версия может служить объяснением того, почему читатель первоначально регистрируется у П. Берынды. Если наше предположение верно, то в русский письменный язык читатель, вероятно, попало из письменности ВКЛ.

Школа [1] ж., перен. То, что дает практические знания, опыт: «В неи отворенная школа учения того» (ПсФ: л. 6).

${ }^{16}$ В «Большом польско-русском словаре» в значении 'читатель' регистрируется также лексема $c z y t a c z$ с пометой «разг.», которая уже не фиксируется в толковых словарях польского языка (БПРС 1: 130). 
Эта лексема, восходящая к греческому scholē 'школа' (первоначально 'досуг, свободное время, праздность', 'медлительность' > 'ученая беседа; диспут'), была заимствована в восточнославянские языки из латыни (schŏla 'ученая беседа', 'школа', 'школа, философское направление') через польское посредничество (см. ФАСмеР 4: 449, ЧЕРныХ 2: 416).

Наиболее ранние фиксации этого существительного отмечаются в сочинениях и письмах А. Курбского, известных в списках XVII в. (LEEMING 1976: 101, ЧЕРныХ 2: 416), в актовом языке ВКЛ школа фиксируется спорадически уже в последней четверти XIV в., регулярно - с XVII в. (БулыкА 1972: 364, БулыкА 1980: 167, ССМ 2: 560, ЕСУМ 6: 433). Как хронологические данные, так и характер памятников, в которых рассматриваемая лексема фиксировалась впервые, свидетельствуют о том, что заимствование из польского языка в русский (см. КоснмаN 1967: 146, SовІК 1969: 366-367, ИСАЧЕНКО-ЛиСОВАЯ 1984: 253, ИСАЧЕНКО-ЛИСОВАЯ 1987: 96, WIтKOWSKI 2006: 239) осуществЛЯлось, вероятнее всего, через посредничество письменности ВКЛ (см. ГАРБУЛЬ 2014: 201).

\section{3. Семантические полонизмы}

Здравый [1] прил. Толковый, рассудительный; трезвый (об уме): «И к таковому своему читанию, приложи свои здравои разумъ: тако истинно все писанное в них, уразумъеш» (ПсФ: л. 8 об.).

Это прилагательное, имеющее общеславянское распространение, является заимствованием из старославянского языка (в древнерусском языке ст.-сл.

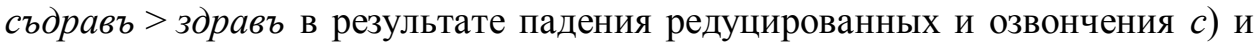
восходит к праслав. ${ }^{*} s b d o r v ъ(j b)$ 'здоровый, крепкий' < и.-е. праформа *sŭdoru-os (*sŭ- 'хорошо', 'здоровый' - приставка *deru- [: *doru-] 'дерево; древесина' - корень) с возможным первоначальным значением 'крепкий, могучий, как дерево' > 'крепкий, полный сил; здоровый’ (см. ФАСМЕР 2: 90, ЭслРЯ 6: 82, 83; Черных 1: 321-322, Boryś 2005: 736).

Уже в языке-источнике, старославянском языке, лексема съдравыи отмечается в переносном значении 'настоящий, истинный, правильный', возможно, ‘благотворный, целительный, целебный; исцеляющий’ (см. СтС 1999: 648). В этих значениях здравый регистрируется и в русской письменности XVI-XVII вв. (СлРЯ XI-XVII вв. 5: 367). Кроме того, в древнерусском языке съдравыи один раз (ХІ в.) фиксируется в переносном значении 'разумный' (СРезНЕвСКИй 3: 698, СлРЯ XI-XVII вв. 23: 250). В сочетании с существительными ум, разум, рассудок, обозначающими мыслительные способности, анализируемое прилагательное впервые встречается в русской письменности в «Истории о великом князе Московском» А. Курбского: «И кто бы, умъ здравъ имъюще, возбранялъ ихъ [замученных] похвалити? Разве бы кто гнусного и ленивого, и лютого, и неистового ума былъ» (см. СлРЯ XI-XVII вв. 5: 367). По нашему мнению, здравый в приведенном выше фрагменте текста 
допускает двоякое толкование: 'здоровый, неповрежденный болезнью (рассудок, ум)' и 'толковый, рассудительный, трезвый (об уме)'. Если у А. Курбского здравый употреблено в первом значении, то тогда отмеченное нами переносное употребление этого прилагательного следует считать одной из наиболее ранних его фиксаций в интересующем нас значении в русском письменном языке. Судя по имеющейся на данный момент информации, в XVII в. прилагательное здравый в анализируемом значении еще не имело широкого распространения, в более активное употребление оно входит в XVIII-XIX вв. (СлРЯ XVIII в. 8: 160, САР 2: 845, ДАль 1: 675) и до сих пор бытует в русском литературном языке в значении 'разумный, правильный, толковый; трезвый, реалистичный' в составе таких сочетаний, как: здравая мысль, здравое рассуждение и т. п., а также во фразеологизме здравый смысл 'трезвое, практическое понимание, отношение к чему-л.; разум, рассудок; рассудительность’ (БАС 6: 699-700, ССРЛЯ 4: 1180-1181). Что касается здравый в значении 'здоровый, неповрежденный болезнью (рассудок, ум)', то оно регистрируется только в современной русской лексикографии в составе фразеологизма кто-л. в здравом уме 'вполне здоровый, хорошо соображающий, психически нормальный человек’ (БАС 2: 700)

Обстоятельства появления здравый как в значении 'здоровый, неповрежденный болезнью (рассудок, ум)', так и в значении 'толковый, рассудительный; трезвый (об уме)' в русском письменном языке (характер памятников, на которые приходятся наиболее ранние фиксации), наводят на мысль о возможной неисконности указанных выше значений рассматриваемой лексемы. С целью проверки этого предположения проследим историю анализируемого прилагательного в тех языках, с которыми у русского языка в XVI-XVII вв. были наиболее активные контакты. Так, в старопольских текстах середины $\mathrm{XV}$ в. zdrowy встречается в словосочетании $z$ zdrowego zamyślenia 'w pełni władz umysłowych, dającej zdolność do działań prawnych, mente sana' (SłStp 11: 300), а с конца того же столетия zdrowy регистрируется в правовых формулах zdrowy $(m)$ być na ciele i na rozumie и na rozumie $i$ na ciele zdrowym być 'być w pełni sił fizicznych i umysłowych, sanum mente et corpore esse' (SłStp 11: 299). Со второй половины XVI в. zdrowy в сочетаниях zdrowy rozum, rozsadek входит в регулярное употребление уже в интересующем нас значении и фиксируется в лексикографических источниках, отражающих польский язык XVIXIX вв. (SłP XVI 36: 459-460, SłP XVII, Linde 6: 992, KarŁowicz 8: 421), и в словаре современного польского языка находим: zdrowy rozum, rozsadek 'rozum, rozsądek opierający się na doświadczeniu, na praktyce życiowej; jasne, proste rozumowanie, pojęcie o czym' (SłJP 10: 989). Другое значение zdrowy 'być przytomnym, świadomym tego, co się dzieje, być normalnym pod względem psychicznym' реализуется во фразеологизмах być przy zdrowych zmysłach, być zdrowym na umyśle (SłJP 10: 989).

В актовом языке ВКЛ в документе второй половины XV в. (1470 г.), насыщенном полонизмами, засвидетельствовано единичное употребление здоровъ на доуши в значении 'при здоровому розумі' (ССМ 1: 394), в котором 
прилагательное здоровый фиксировалось также в XVI-XVII вв. (СУМ 2: 27). В переносных значениях здоровый наблюдается в письменности ВКЛ с XVIXVII вв.: в значении 'істинний, правильний, правдивий, непомильний' - с последней четверти XVI в., а в значении 'тверезий, розсудливий' - со второй половины того же столетия, в сочетании здоровый розумъ-с 10-х гг. XVII в. (СУМ 11: 200, ГСБМ 12: 184). Прилагательное здравый в первом из указанных выше переносных значений отмечается здесь с 60-х гг. XVI в., а во втором - с начала XVII в., в составе сочетания здравый разумь - с 20-х гг. того же столетия (ГСБМ 12: 187, СУМ 11: 203). Следует заметить, что как здоровый, так и здравый в указанных выше значениях во второй половине XVI первой половине XVII в. представлены в деловых актах и текстах на «простой мове», в той или иной степени испытавших польское влияние. Со второй половины XVII в. в письменности ВКЛ в интересующем нас значении начинает доминировать здоровы $\check{u}^{17}$ (Тимченко 1: 317). В словаре современного белорусского языка здаровы также регистрируется в значении 'разважны, разважлівы, разумны', в том числе и в составе сочетания здаровы розум (ТСБМ 2: 459), и в словаре современного украинского языка находим здоровий 'то же', в том числе в составе сочетания здоровий розум 'здравый смысл' (ВТССУМ 2005: 455).

Если сопоставить факты из истории $z d r o w y$ в анализируемом употреблении в польском и здравый, здоровый в восточнославянских языках, то, по нашему мнению, есть определенные основания для предположения о возможности семантического заимствования в последние из польского языка. При этом в русский письменный язык как значение 'здоровый, неповрежденный болезнью (рассудок, ум)', так и интересующее нас переносное употребление попали, видимо, благодаря деловой письменности ВКЛ и «простой мове».

Играние [2] с. Игра на музыкальном (-ых) инструменте (-ах), исполнение музыкального произведения: «Иже гдђ написано токмо псалом, тогда тамо разумъи едино точию играние иструмента» (ПсФ: л. 8). «А идъ же стоит пъснь, тамо разумђи точию гласъ человђческии, кромђ играния иструментнаго» (ПсФ: л. 8).

Данная лексема представляет собой суффиксальное отглагольное образование (о происхождении глагола играть см. выше - приигрывати).

В древнерусском языке играние в значении «действие по глаг. играти 'играть, забавляться; заниматься игрой, принимать участие в игре; резвиться; игра, представление'» отмечается с XI-XII вв. (СРЕзнЕвский 1: 1020, СлДРЯ 3: 443, 444). В интересующем нас значении, по данным исторических словарей (СлДРЯ 3: 443-444, СлРЯ XI-XVII вв. 6: 81), данная лексема также могла быть известна уже в древнерусском языке. Однако единственный пример конца XIV века, иллюстрирующий в «Словаре древнерусского языка» упот-

${ }^{17}$ В русском письменном языке XVI-XVIII вв., в отличие от письменности ВКЛ, здоровый не зафиксировано в анализируемом нами переносном значении. 
ребление играние, не позволяет однозначно установить значение (СлДРЯ 3: 443-444): на наш взгляд, данное существительное в цитируемом тексте употреблено в значении 'массовые игры; зрелища'. В «Словаре русского языка XI-XVII вв.» наиболее ранняя фиксация играние в рассматриваемом нами значении представлена цитатой из «Девгениева деяния» XI-XII вв. в списке XVIII в (СлРЯ XI-XVII вв. 6: 81). Таким образом, на данный момент ПсФ является тем источником, в котором зафиксировано одно из наиболее ранних конкретно датированных употреблений играние в значении 'игра на музыкальном (-ых) инструменте (-ax), исполнение музыкального произведения'. Далее это слово в исследуемом значении регистрируется в словарях, отражающих русский язык XVIII-XIX вв. (СлРЯ XVIII в. 8: 248, САР 2: 945, ДАль 2: 7). В словаре современного русского языка играние снабжено пометой «устар.» (БАС 7: 26).

По мнению Т. А. Исаченко, играние 'игра на музыкальных инструментах’ - это заимствование из польского (ИСАчЕнко 1987: 80-81). Уточним, что в данном случае следует говорить о семантическом заимствовании, и попытаемся обосновать это, опираясь на новейшие данные исторической лексикографии. В польских письменных источниках granie в значении 'wydobywanie tonów, melodii z instrumentów muzycznych' спорадически фиксируется в середине второй четверти XVI в., регулярно - с 60-х гг. того же столетия (SłP XVI 8: 107). В данном значении лексема бытовала в польском языке на протяжении XVII-XIX вв. (SłP XVII, Linde 2: 118, KARŁOWICZ 1: 901) и входит в активный запас лексики современного польского языка (SłJP 2: 1288).

В письменности ВКЛ анализируемое существительное в форме играние, игранье в значении 'забава, гра' наблюдается с конца XVI в., а в значении 'грання, гра на музичних інструментах' в формах играние, игранье и граньес конца первой четверти XVII в., причем в обоих значениях это слово на первых порах отмечалось в текстах, язык которых в значительной степени насыщен полонизмами, или в переводах с польского (СУМ 7: 78-79, СУМ 13: 18, ГСБМ 7: 141, ГСБМ 14: 6). В белорусском языке ХІХ в. в интересующем нас значении анализируемое слово употреблялось в форме гра́нне (Носович 1870: 121), а в украинском языке того же периода - в форме грання (ГРінченко 1: 322). В словаре современного белорусского языка эта лексема регистрируется в форме ігра́нне (ТСБМ 2: 527), а в словаре современного украинского языка - в форме грання (ВТССУМ 2005: 259).

Приведенная выше информация, по нашему мнению, дает определенные основания для того, чтобы считать играние в рассматриваемом значении в русском языке семантическим заимствованием из польского. Что касается других восточнославянских языков, то не исключено, что здесь это слово может быть лексическим заимствованием из того же источника. Сопоставление хронологических данных позволяет предполагать посредничество письменности ВКЛ при заимствовании играние 'игра на музыкальном (-ых) инструменте (-ax), исполнение музыкального произведения' в русский письменный язык XVII в. из польского. 
МЊшати [1] несов. Путать, принимать одно за другое; смешивать: «И кто сию... книгу... будетъ читать с разумом... и ръчь со иною рђчию не будетъ мъ шать; таковыи истинно уразумђеть всьх псалмовъ и стихов разум» (ПсФ: л. 7).

В одном из исследований, посвященных анализу семантических полонизмов в русском приказном языке, мы привели достаточно убедительные доказательства того, что мъшати в указанном выше значении является семантическим заимствованием из польского, которое проникло в русский деловой язык в середине XVII в., вероятнее всего, благодаря посредничеству письменности ВКЛ (см. ГАРБУЛь 2009: 144-145).

Належащий [1] прич. в знач. прил. Насущный, необходимый, нужный; важный; полезный, годный: «И тоя ради вины... истолкованы псалмы, на наш простои словенскои языкъ, с великим прильжанием: самои належащии, истинныи в них... разум, без всякаго украшения» (ПсФ: л. 7).

Глагол належати, мотивирующий анализируемую лексему, в таких значениях, как 'относиться, принадлежать' и 'состоять, заключаться' считается семантическим полонизмом в русском языке (см. WITKOWSKI 1992: 266, WITKowsKi 2006: 115, Целунова 2006: 130). ${ }^{18}$ Что касается глагола належати и производного от него причастия належащиий в интересующем нас значении, то они не представлены ни в одном лексикографическом источнике русского языка. Наиболее близкие к рассматриваемому нами переносные значения належати 'быть присущим чему-л., соответствовать', 'следовать, быть должным, надлежать' спорадически отмечаются в древнерусских памятниках уже в XIV в. (СлДРЯ 5: 155). В этих значениях глагол бытовал на протяжении XV - первой четверти XVIII в. (СлРЯ XI-XVII вв. 10: 132, СлРЯ XVIII в. 13: 227). Причастие належащий 'надлежащий, должный, соответствующий; полагающийся', мотивированное приведенными выше значениями глагола, в функции прилагательного впервые регистрируется в начале 20-х гг. XVII в. в «Вестях-Курантах» ${ }^{19}$ (см. СлРЯ XI-XVII вв. 10: 133). Как история глагола, так и история причастия в представленных выше значениях ограничивается в русском языке первой четвертью XVIII в., причем причастие в значении прилагательного в первой четверти XVIII в. отмечено в письменных источниках только два раза, и одно из этих употреблений обнаружено в переводе с польского языка (СлРЯ XVIII в. 13: 227).

В памятниках польской письменности и глагол należeć в значениях 'być przyznaczonym, służyć', 'być ważnym, koniecznym', и причастие należacy 'przeznaczony, służący komu, czemu, używany albo przydatny do czego; pertipens;

18 Этот автор, на наш взгляд, неверно установил значение належащиий в приведенном выше контексте, он считает, что причастие образовано от належати в значении 'относиться, принадлежать' (ЦелуновА 2006: 513).

${ }^{19}$ В других значениях эта лексема фиксируется в русском письменном языке с XVI в. (СлРЯ ХI-XVII вв. 10: 132-133). 
nĕcessārius; spectans; competens' известны с конца 50-х - середины 60-х гг. XVI в., а причастие в значении прилагательного - с середины 90-х гг. того же столетия (SłP XVI 15: 629, 632-633, 633-634). В этом значении обе лексемы бытовали до начала XVIII в. (SłPaska 1: 466, LINDE 3: 249-250). В словаре, отражающем польский язык XIX века, należé в значении 'być potrzebnym; być koniecznym, nieodzownym' уже снабжено пометой «staropolski» (cм. KarŁowiCz 3: 92).

В деловом языке ВКЛ и текстах на «простой мове» со второй половины 60-х гг. XVI в. глагол належати засвидетельствован в значении 'падыходзіць, адпавядаць' (ГСБМ 19: 112), а с конца того же столетия - в значении 'иметь значение, быть важным' (Тимченко 1: 459). С середины XVII в. в письменности ВКЛ регистрируется причастие належащчй, мотивированное первым из указанных выше значений глагола (ГСБМ 19: 114), а со второй половины XVI в. - причастие належачий в том же значении и в значении 'належны' в функции прилагательного (ГСБМ 19: 113). Заметим, что належащий в приведенном выше значении в историческом словаре иллюстрируется единственным примером, тогда как належачий в обоих значениях имело более широкое распространение, при этом обе лексемы встречаются в текстах, язык которых в значительной степени насыщен полонизмами. Далее находим належаць 'быць неабходным' в словаре современного белорусского языка, где в значении 'такі, які павінен быць; патрэбны, неабходны' представлено уже только прилагательное належны (ТСБМ 3: 265). В словаре современного украинского языка належати фиксируется в значении 'бути властивим, притаманним кому-н., чому-н.', а в значении 'який потрібний, необхідний; відповідний', как и в белорусском языке, мы находим прилагательное належний ${ }^{20}$ (ВТССУМ 2005: 721).

Опираясь на приведенную выше информацию, мы склоняемся к мнению, что слово належащ⿻ий в анализируемом значении, обнаруженное в «Предисловии к читателю» ПсФ, является окказиональным семантическим полонизмом. Что касается письменности ВКЛ, которая могла способствовать проникновению его в русский письменный язык XVII в., то здесь належащчй также, видимо, семантическая калька с польского, потому что это причастие в других значениях известно с начала 30-х гг. XV века (ГСБМ 19: 114), а належачии, возможно, - лексическое заимствование из того же источника, поскольку эта лексема здесь спорадически отмечается в 30-50-е гг. XVI в., peгулярно - с последней четверти того же столетия, причем во всех значениях она фиксируется в текстах, испытавших сильное влияние польского языка (ГСБМ 19: 112-113).

Народъ [1] м. Население государства, страны, какой-л. территории; люди, принадлежащие к одной этнической общности, народность, народ: «По1: 460).

${ }^{20}$ В историческом словаре украинского языка оно имеет помету ' $n л$. należny“ (Тимченко 
неже нашъ росиискии ${ }^{21}$ народ грубыи, и неученыи, не токмо простыя, но и духовнаго чина» (ПсФ: л. 3).

Анализируемое существительное имеет общеславянское распространение и восходит к праславянскому *narodb, развитие семантики которого можно представить следующим образом: первоначально 'рождение, происхождение, начало' > 'то, что родилось' > 'род живых существ' > ' род человеческий', 'род', 'племя' > 'народ, нация' (см. ЭССЯ 22: 254). С точки зрения происхождения это слово является сложением префикса *na- и *rodb либо отглагольным образованием от *naroditi 'родить', 'уродить, принести плоды', префиксального производного от праслав. *roditi, 1 л. ед. ч. *rodjo ‘производить потомство’, ‘давать, приносить плоды, плодоносить', восходящего к праслав. *rodb 'род, племя' < и.-е. корень *uerd ${ }^{h}$ : *ured ${ }^{h}$ - (: *urōdh $\left.d^{h}\right)$ 'расти', 'разрастаться', 'прибывать; подниматься' (см. ЭССЯ 22: 253-254, Черных 2: 118-119, ФACMEP 3: 45, 490-491, 492; Boryś 2005: 352, 516, 524).

В древнерусском языке народъ в значениях 'народ, люди', 'множество, толпа, сонм', 'простой народ' наблюдается с XI-XII вв. (СРезНЕвский 2: 320321, СлДРЯ 5: 183-184, СлРЯ XI-XVII вв. 10: 214-215). В памятнике XIV в. засвидетельствовано единичное употребление народъ в значении 'племя, народность’ (СлДРЯ 5: 184). В интересующем нас значении это существительное впервые регистрируется в русской письменности в начале второй четверти XVII в. в переводном с польского языка тексте, где оно сопровождается пояснением: «Народы... различныя суть и чины розные имђютъ (nacye)» (см. СлРЯ XI-XVII вв. 10: 215). В этом значении анализируемое слово бытовало на протяжении XVIII-XX вв. и до сих пор входит в активный состав русской лексики (СлРЯ XVIII в. 14: 17-18, ДАль 2: 461-462, БАС 11: 327).

Учитывая характер памятника, на который приходится наиболее ранняя фиксация лексемы народъ в анализируемом значении, на наш взгляд, есть некоторые основания предполагать возможность семантического калькирования с польского. В старопольской письменности naród отмечается с первой половины XV в. в значении 'potomstwo, dzieci', a co второй половины того же столетия - в значениях 'pokolenie', 'ród, rodzina, krewni' и 'plemię, lud (natio - с середины XV в., gens, gentis - с конца того же столетия)’ (SłStp 5: 91-92). С конца первой четверти XVI в. данное слово известно также в значении 'społeczność ludzka związana tradycją kulturową, obyczajami, językiem, tworząca wspólnotę polityczną i gospodarczą', в котором оно употребляется уже около пяти столетий (SłP XVI 16: 169-172, SłPaska 1: 473-474, Linde 3: 274, KaRŁowICZ 3: 151, SłJP 4: 1176).

В письменности ВКЛ лексема народъ впервые регистрируется в конце 80-х гг. XV в. в значении 'людзі; народ', а с 80-х гг. XVI в. она наблюдается здесь и в интересующем нас значении 'людзі, якія належаць да адной этнічнай ці расавай супольнасці; народнасць, нацыя, народ’, в котором на первых

${ }^{21}$ В «Объяснении переводчика» в глоссе в соответствии с росиискии используется московскии (см. ЦелУновА 2006: 181). 
порах (последняя четверть XVI - начало XVII в.) отмечалась в текстах, в значительной степени насыщенных полонизмами, или в переводах с польского языка (ГСБМ 19: 261-262). В интересующем нас значении анализируемое существительное представлено также в словарях современного белорусского (ТСБМ 3: 300-301) и украинского (ВТССУМ 2005: 733) языков.

Итак, приведенная выше информация не противоречит высказанному выше предположению о том, что лексема народъ в рассматриваемом значении в русском языке может быть семантическим заимствованием из польского. Что касается других восточнославянских языков, то не исключено, что здесь это слово является лексическим полонизмом. В связи с этим примечательно, что П. Берында фиксирует его с ударением на первом слоге («на́родъ, языкъ: людъ») (БЕРындА 1627: л. 132). Данные хронологии позволяют, по нашему мнению, говорить о том, что в русский письменный язык рассматриваемое значение лексемы народъ попало, очевидно, благодаря деловой письменности ВКЛ и «простой мове».

Недостаточный [1] прил. в знач. сущ. Не имеющий достатка, небогатый; неимущий, бедный: «А убогии, и недостаточныл, да научится на своем доволну быть» (ПсФ: Л. 6).

Т. А. Исаченко относит недостаточный в приведенном выше значении к полонизмам (ИСАЧЕНКо 1987: 83). Следует уточнить, что в данном случае речь может идти только о семантическом заимствовании, так как в древнерусском языке это прилагательное в значении 'несовершенный, имеющий недостатки’ и ряде других значений было известно с последней четверти XI в. (СРезНевский 2: 376, СлДРЯ 5: 257, СлРЯ ХІ-XVII вв. 11: 97). В интересующем нас значении эта лексема представлена единичным употреблением уже в древнерусском источнике XIV в. (СлДРЯ 5: 257), затем - также спорадически - в русской письменности конца XV в., более регулярно она регистрируется начиная с XVII в. (СлРЯ XI-XVII вв. 11: 97). В значении 'не имеющий достатка, небогатый’ недостаточный бытовало в русском языке XVIII-XIX вв. (СлРЯ XVIII в. 14: 172, ДАль 2: 515). В словаре современного русского языка недостаточный 'не имеющий достатка; небогатый, неимущий' снабжено пометой «устар.» (БАС 11: 622).

В старопольском языке niedostateczny 'ubogi, biedny, niemajętny, potrzebujący’ регистрируется с XIV в. (BAŃKOWSKI 2: 301, SłStp 5: 173). В данном значении анализируемая лексема продолжала активно употребляться в XVXVI вв. (RECZEK 1968: 240, SłP XVI 17: 238-239). Для польского языка история niedostateczny в значении 'niezasobny, niezamożny, ubogi, biedny' ограничивается первой половиной XVII в., в лексикографическом источнике, отражающем польский язык XIX в., интересующее нас значение сопровождается пометой «staropolski» (KARŁowICZ 3: 276).

В письменности ВКЛ прилагательное недостаточный, недостатечный с первой четверти XVI в. засвидетельствовано в значениях 'недастатковы; які не адпавядае чаму-н., якім-н. патрэбам', 'мізэрны; хворы; які мае адмоў- 
ныя рысы або фізічны недахоп', а со второй четверти того же столетия в значении 'бедны, убогі' и в роли существительного в значении 'бедняк', причем в двух последних случаях данная лексема отмечается в деловых документах и текстах на «простой мове», насыщенных полонизмами (ГСБМ 20: 88-89). За пределами XVII в. судьба недостаточный, недостатечный ни для белорусского, ни для украинского языка не прослеживается.

Представленные выше данные, по нашему мнению, дают определенные основания для того, чтобы считать анализируемое прилагательное лексическим заимствованием из польского в письменности ВКЛ. Что касается русского языка, то здесь можно допустить только семантическое калькирование с польского, причем спорадические употребления недостаточный в анализируемом значении в XIV и XV веках следует рассматривать как предысторию прилагательного в данном значении в русском языке. В таком случае в XVII в. произошло либо повторное заимствование из польского, либо польский язык и, возможно, письменность ВКЛ просто способствовали активизации употребления недостаточный в интересующем нас значении в русском письменном языке.

Неспьшно [4] нареч. Медленно, неторопливо; без поспешности: «А паче же да прочитаем сию святую книгу... с разумом, и несnъuно» (ПсФ: л. 5 об.). «И кто сию святую книгу... будеть читать с разумом, несп ъино, смотря запятых, и точекъ... таковыи истинно уразумъетъ всђх псалмовъ... разум» (ПсФ: л. 7). «И ты сыскав в неи, псалмы молитвенныя, и читаи их несnъшно, с разумом» (ПсФ: л. 7). «Естли будешъ ихъ с разумом, и неспьино читать, всђ... псалмы самъ истинно познаеш» (ПсФ: л. 7 об.).

В монографии «Семантические полонизмы в русском приказном языке первой половины XVII века» мы приводим аргументы, свидетельствующие о том, что несnъuно в приведенном выше значении является семантическим полонизмом, который попал в русский письменный язык во второй половине XVI - начале XVII века (см. ГАРьуль 2009: 262-264). В письменности ВКЛ неспешно 'няспешна', известное с первой половины XVII в., по нашему мнению, представляет собой лексическое заимствование из того же источника (ГАРБУль 2009: 263-264).

Потреба [1] в сост. сказ. Нужно, необходимо; следует: «Сего ради потреба тебъ въдати любезныи читателю» (ПсФ: л. 7 об.).

В отношении происхождения этой лексемы, имеющей общеславянское распространение, мнения расходятся: одни исследователи считают, что праслав. *poterba 'то, что необходимо, обязательно; необходимость, нужда' является дериватом от праслав. *poterbovati 'испытывать недостаток в чем-л.', 'сильно хотеть, желать чего-л.', приставочного производного от праслав. *terbovati 'нуждаться в чем-Л.; требовать чего-л.' (см. BORYŚ 2005: 471), другие предполагают, что анализируемое слово возникло на базе выражения 
*trěbě byti 'быть нужным, необходимым', дополненного предлогом *po, так как *trěbě понималось как форма местного падежа, который употреблялся только с предлогом, ${ }^{22}$ а затем на основе *po trěbě была реконструирована форма именительного падежа *potrěba (см. ЭСБМ 8: 219, BAŃKOWSKI 2: 727). Что касается происхождения корневой морфемы рассматриваемого слова, то ее возводят к и.-е. *ter $b^{h}$ - (корень *terə-: *trēi-: *trī-) 'тереть', 'поворачивать', 'крутить' или 'сверлить', сближаемому некоторыми исследователями с и.-е. *terp-: *trep-: ‘приносить пользу', ‘насыщаться', 'радоваться’ (см. ФАСмЕР 4: 45-46, 96; Pokorny 1: 1071, 1073; Черных 2: 237, 259; BRÜCKNER 1974: 579, BORYŚ 2005: 648, REJZEK 2001: 679). Восточнославянские формы на трђб-: треб- (при древнерусском тереб-) считаются заимствованием из старославянского (церковнославянского) языка (см. ФАСмЕР 4: 96, ЧЕРных 2: 259), но в отношении украинского языка высказывается предположение о возможном влиянии польского на появление этих форм (см. ЕСУМ 5: 626).

Существительное потрђба, потреба в различных значениях отмечается в древнерусском языке с XI-XIII вв. (СРезнЕвский 2: 1296-1297, СлДРЯ VII: 348-349, СлРЯ XI-XVII вв. 18: 18-19) и в значении 'нужда, надобность, потребность, необходимость' входило в активный лексический запас русского языка до XX в. (САР 5: 83, ДАль 3: 358). В словаре, отражающем современный русский язык, потреба в указанном выше значении сопровождается пометой «устар.» (ССРЛЯ 10: 1635). Под это значение в словаре древнерусского языка помещено два употребления потрьба, потреба (есть) в роли сказуемого 'надо, следует': одно датировано 1076 г., другое - XIV в. (по памятнику в списке XV в.) (СлДРЯ 7: 349). Анализ контекстов этих употреблений показывает, что только во втором случае потреба используется в составе сказуемого. Таким образом, наиболее раннюю фиксацию лексемы потреба в интересующем нас значении следует отнести к XV в.

Мы обнаружили потреба 'нужно, необходимо; следует' в «Предисловии к читателю» ПсФ, другие примеры употребления этого слова в XVI-XVII вв. нам неизвестны. В интересующем нас значении потреба фиксируется в лексикографических источниках, регистрирующих русский язык XVIII-XIX вв. (CAP 5: 83, Даль 3: 358). За пределами XIX в. судьба слова потреба в значении 'нужно, необходимо; следует' для русского языка не прослеживается.

История лексемы потреба в анализируемом значении в русском языке, а также мнение А. Баньковского о том, что в белорусском и украинском языках она является полонизмом (BAŃKOWSKI 2: 727), наводят на мысль возможном семантическом заимствовании в русский язык из польского. Тем более что уже в древнерусском языке в том же значении употреблялись однокоренные наречия потрьбно, потреб(ь)но и потреб(ь)нъ '(в сост. сказ.) нужно, необходимо'. ${ }^{23}$ В русском письменном языке непрерывная история потребно

\footnotetext{
${ }^{22}$ См. Топоров 1961: 36-37, 55-56, 82-83, 88-90, 103, 109, 113-115, 285-286, 303-304.

${ }^{23}$ В связи с этим примечательно, что в рукописи Б потреба заменено на потребно (см. Целунова 2006: 186, сноска 97).
} 
прослеживается до второй четверти XIX века (СлДРЯ 7: 354-355, СлРЯ XIXVII вв. 18: 21-22, CAP 5: 84).

В старопольских памятниках существительное potrzeba наблюдается c XIV в. (BoRYś 2005: 471). С конца первой четверти XV в. оно встречается в употреблении jest (czegoś) potrzeba 'coś jest niezbedne, aliquid něcessārium est', ${ }^{24}$ а со второй половины XV в. отмечается potrzeb 'należy, wypada, trzeba, ŏportet, decet, něcessě est' (SłStp 6: 495, 496-497), которое возникло на базе potrzeba jest, с последующей утратой глагола (BoRYś 2005: 471). Широкое распространение potrzeba в предикативной функции в значении 'coś jest potrzebne, trzeba, należy, wypada' получает в начале XVI в., постепенно вытесняя potrzeb в этом употреблении (SłP XVI 28: 429, 430, 430-431, 452-458). $\mathrm{B}$ интересующем нас значении слово potrzeba активно употреблялось в польском языке на протяжении XVII-XX вв. вплоть до настоящего времени (SłP XVII, LiNDE 4: 410, KARŁOWICZ 4: 818, SłJP 6: 1211).

В письменности ВКЛ спорадическое употребление лексемы потреба, в том числе и в значении '(предик.) треба, потрібно', отмечается в документах конца XIV - первой четверти XV в., в языке которых заметно польское влияние (ССМ 2: 213, 214, ГСБМ 27: 321). В документах конца XV в., насыщенных полонизмами, в интересующем нас значении спорадически встречается также слово потребъ (ГСБМ 27: 331). Более регулярно потреба в значении 'трэба, неабходна (зрабіць што-н.)' регистрируется со второй половины XVI в. в текстах на «простой мове», в которых заметно сильное влияние польского языка (см. ГСБМ 27: 321, Тимченко 2: 194). Что касается слова потребъ в том же значении, то уже в XVI в. фиксируются лишь единичные его употребления и далее этого столетия история его не прослеживается (ГСБМ 27: 331, Тимченко 2: 194). В интересующем нас значении потреба бытовало в белорусском языке еще в XIX в. (Носович 1870: 484). В украинском языке история этой лексемы в анализируемом значении ограничивается первой третью XVIII в. (Тимченко 2: 194).

Сопоставление приведенной выше информации, по нашему мнению, дает определенные основания для вывода о том, что в русском языке потреба в значении 'нужно, необходимо; следует', вероятнее всего, представляет собой семантическое заимствование ${ }^{25}$ из польского. ${ }^{26}$ При этом единичная

${ }^{24}$ Не исключено, что в старопольском употребление jest (czegoś) potrzeba появилось под влиянием старочешского (jest) potřěba čeho, s inf. 'je potřeba, je třeba, je zapotřebí', которое peгистрируется в памятниках с 40-х гг. XIV в. (StčSl 5: 891).

${ }_{25}$ Мы склонны квалифицировать этот случай как семантическое заимствование, опираясь на то, что в исторических и толковых словарях польского языка, а также в толковых словарях русского языка существительное потреба и потреба в предикативной функции не трактуются как омонимы, как это делается в исторических словарях белорусского и украинского языков.

${ }^{26}$ Косвенным подтверждением этого может служить то, что заимствованием из польского в русском языке считается другое значение слова потреба 'бой, сражение, стычка' (см. СлРЯ XI-XVII вв. 18: 19), а также однокоренная лексема треба 'надо, нужно, необходимо, требуется; следует’ (см. WITKOWSKI 2006: 211, ГАРБУль 2014: 183). 
фиксация лексемы в интересующем нас употреблении в XV в. может рассматриваться как предыстория анализируемого значения в русском языке. Что касается происхождения слова потреба в других восточнославянских языках, то не исключено, что там оно является лексическим полонизмом. Более раннюю его фиксацию в письменности ВКЛ по сравнению со старопольским языком можно объяснить исключительным доминированием латыни в польской деловой письменности в средневековье (ЗолтАН 2014: 109). Деловой язык ВКЛ и «простая мова», по-видимому, играли роль посредников в процессе заимствования потреба 'нужно, необходимо; следует' в русский письменный язык из польского.

Разобрати [2] сов. Рассмотреть; разобрать(ся), распознать, различить; установить, определить; постичь, уяснить себе: «Естли будешъ ихъ с разумом, и неспьшно читать, всъ сии псалмы самъ истинно познаеш, и их разбереш» (ПсФ: л. 7 об.). «По надписанию их любезныи читателю самъ разберешъ, и увьдаешъ истинно» (ПсФ: л. 8).

Это слово представляет собой префиксальное производное, восходящее к имеющему общеславянское распространение праслав. *bbrati, 1 л. ед. ч. *berq 'брать', 'собирать, срывать (плоды)', связанному с и.-е. *bher- (: *bherz- : *bhr-) с первоначальным значением 'нести', на базе которого в славянских языках развивалось значение 'брать', сначала появившееся, видимо, у приставочных глаголов, а затем распространившееся на первообразную форму (см. ФАСмеР 1: 159, ЭССЯ 3: 162-163, ЧерныХ 1: 109, BorÝ́ 2005: 37).

В русском письменном языке наиболее ранняя фиксация перфектива разобрати 'отделить' приходится на «Никоновскую летопись» (под 1380 г.), известную в списке XVI в. (вариант XVII в.), а регистрация имперфектива разбирати 'раскладывать по отдельности, отделять (одно от другого) - на памятник XIV в., известный в списке XVI в., затем разобрати в различных значениях, а разбирати в значении 'разбирать, разнимать что-л. по частям' отмечается в последней четверти XV в. (СлРЯ XI-XVII вв. 21: 137, 232-233). Согласно данным исторического словаря, в переносных значениях единичные употребления имперфектива разбирати впервые встречаются во второй половине XVII в.: в значении 'рассматривать в сравнении с прочими, принимать во внимание отличительные черты' - в произведении Аввакума «О пресвятой богородице», а в значении 'понимать; разбирать(ся), 27 - в «Записках» Сильвестра Медведева (СлРЯ XI-XVII вв. 21: 137-138). Что касается перфектива разобрати, то в переносном значении 'рассудить, разобраться' до сих пор также было известно два наиболее ранних случая его употребления, датируемых второй половиной XVII в.: один обнаружен в «Житии» протопопа Аввакума (1673 г.), другой - в деловом акте 1683 г. (СлРЯ XI-XVII вв. 21:

${ }^{27}$ Составители исторического словаря русского языка это значение не установили, по нашему мнению, в приведенной в этом источнике иллюстрации разбирати, видимо, употреблено в указанном значении. 
233). В лексикографических источниках, отражающих русский язык XVIIIXIX вв., разбирать, разобрать представлены в значениях 'разсматривать, разсуждать, изсльдывать' и 'понимать, познавать, имъть нЊкоторое познаніе' (CAP 5: 794-795, ДАль IV: 14). И в современном русском языке разбирать, разобрать бытуют в переносных значениях 'уяснить себе, постичь; познать, распознать', 'исследуя, выяснить, определить, дать оценку чему-л.' (ССРЛЯ 12: 118, БАС 22: 159-160).

История как разобрати, так и разбирати в интересующем нас переносном значении в русском языке (характер памятников, в которых выявлены наиболее ранние их употребления, спорадичность как перфектива, так и имперфектива в этих значениях в памятниках XVII в.) может свидетельствовать о неисконности этих значений. Если это предположение верно, то возможным источником семантического калькирования был польский язык. Так, вероятнее всего, семантическими полонизмами являются разбирати 'разнимать на члены' и 'раздевать' (см. СлРЯ XI-XVII вв. 21: 137, 138). В. Витковский также относит к семантическим заимствованиям из польского разбиратися 'раздеваться' (WITкоWSкI 1992: 267, WiткоWSкі 2006: 186), однако этот случай следует, видимо, квалифицировать как лексическое заимствование, так как разбиратися/розбиратися впервые фиксируется в русской письменности именно в этом значении (СлРЯ XI-XVII вв. 21: 138).

В старопольском языке rozebrać, rozbrać уже с середины 30-х гг. XV в. засвидетельствованы в переносном значении 'wyznaczać, ustalać, constĭtuĕre, stătuĕre’ (StStp 7: 517). C середины XVI в. rozebrać отмечается в значении 'dokładnie rozpatrzyć jakąś sprawę, rozmyślając nad nią lub omawiając ją; przeanalizować tekst' (SłP XVI 36: 76-77). В переносном значении 'wziąć pod rozbiór, roztrząsnąć, rozeznać, rozpoznać, rozważyć, przedysputować, rozpatrzyć, zbadać szczegółowo; poddać krytyce, ocenić krytycznie' rozebrać представлено в словарях, регистрирующих польский язык XVIII-XIX вв. (см. LINDE 5: 89, KARŁOWICZ 5: 602). В значении 'rozpoznać, pojąć, zrozumieć' данная лексема в XIX в. фиксировалась уже только в диалектах польского языка (KARŁOWICZ 5: 602). В словаре современного польского языка rozebrać в значении 'rozpatrzyć, rozważyć co; roztrząsnąć, zbadać szczegółowo; interpretować' снабжено пометой «przestarz.» (SłJP 7: 1069).

В деловом языке ВКЛ под 1578 г. отмечен один случай употребления розобрати в значении 'разглядзець, абмеркаваць, ${ }^{28}$ в середине XVII в. в тексте на «простой мове» в том же значении встречается розебрати, которое считается заимствованием из польского (ГСБМ 30: 216, 271; БУлЫКА 1972: 285). Имперфектив розбирати в том же значении 'разглядаць; абмяркоўваць' встречается в текстах на «простой мове» с последней четверти XVI - начала XVII в ${ }^{29}$ и имел более широкое распространение по сравнению с перфективом (ГСБМ 30: 163). В источнике начала 60-х гг. XVI в. засвидетельствовано

${ }^{28}$ В прямом значении розобрати - с начала XVI в. (ГСБМ 30: 270).

${ }^{29}$ В прямом значении розбирати - с конца 20-х гг. XVI в. (ГСБМ 30: 162). 
наиболее раннее употребление розбирати в значении 'уясняць для сябе, усведамляць', которое более регулярно отмечается в письменности с конца XVI первой четверти XVII в. (ГСБМ 30: 163). Следует заметить, что и розобрати, розебрати и розбирати в интересующих нас значениях наблюдаются в деловых актах и текстах на «простой мове», которые испытали заметное влияние польского языка, а также в переводах с польского. В форме разобрати, разбирати анализируемый глагол в интересующем нас значении в письменности ВКЛ не зарегистрирован (см. ГСБМ 29: 445, 463). Перфектив розібра$m u$ 'разобрать, понять, взять в толк' и имперфектив розбірати 'разбирать, понимать' представлены в лексикографическом источнике, фиксирующем украинский язык XIX в. (ГрІнченко 4: 31). В современных белорусском (разабраць, разбіраџь) и украинском (розібрати, розбирати) языках (ТСБМ 4: 564, 571, ВТССУМ 2005: 1231) анализируемая лексема употребляется в тех же переносных значениях, которые были указаны выше для современного русского языка.

Факты из истории разобрати/розобрати, разбирати/розбирати в анализируемом переносном значении в восточнославянских языках и rozebrać в польском языке дают, на наш взгляд, определенные основания для заключения о том, что в первых мы имеем дело с семантическим заимствованием, ${ }^{30}$ проникновению которого в русскую письменность второй половины XVII в. из польского могли способствовать актовый язык ВКЛ и «простая мова».

Спњшно [1] нареч. Поспешно, торопливо; быстро: «Аще кия читают сии псалмы, cnъшно, // и неблагоискусно, без разсуждения, таковыя, ни себе ни иных не ползуют» (ПсФ лл. 8 - 8 об.).

Анализируемое наречие, вероятнее всего, образовано суффиксальным способом от прилагательного, восходящего к праслав. *spěšsnъ(jb) 'скорый, быстрый; проворный', 'удачный, успешный', в свою очередь, суффиксальному производному от *spěch 'поспешность, торопливость, спешка', являющемуся отглагольным дериватом от праслав. *spěti, 1 л. ед. ч. spějg 'удаваться' > 'развиваться' > 'устремляться' > 'спешить, торопиться' < и.-е. корень *sp $(h) \bar{e}(i)-:$ *sphē-: *sphə-: *spi- ‘быть в состоянии, мочь', ‘удаваться', ‘иметь успех, преуспевать', 'прибавляться', 'успеть, успевать' (см. BRÜCKNER 1974: 509, Boryś 2005: 469, 619-620; ПРЕОБРАЖЕНСКИЙ 2: 367-368, ФАСМЕР 3: 734, 735; ЧЕрных II: 193, ЭСБМ 12: 265, 275-276).

Наиболее раннее употребление наречия сnъшно 'прилежно, старательно, ревностно' отмечается в «Изборнике великого князя Святослва Ярославича 1073 г.» в списке конца XV века, ${ }^{31}$ во всех других значениях, в том числе и в интересующем нас, оно впервые регистрируется в памятниках, известных в списках XVI в. (СлРЯ XI-XVII вв. 27: 30). Так, в значении 'спешно; быстро’

\footnotetext{
${ }^{30}$ При этом розебрати в письменности ВКЛ, очевидно, является лексическим заимствованием из польского.

${ }^{31}$ О датировке этого списка см. МушинскАЯ 2010: 84.
} 
сnъшно наблюдается в ряде летописных сводов: «Московском летописном своде» - под 1150 г., «Никоновской летописи» - под 1204 г., «Львовской летописи» - под 1408 г., причем запись в первом источнике, а также деловые акты, где это слово засвидетельствовано в первой половине XVII в., представляют собой дипломатическую документацию (СлРЯ XI-XVII вв. 27: 30). В форме сnъшнъ в интересующих нас значениях 'скоро', 'поспешно, быстро' данная лексема также регистрируется только в XVI веке, тогда как в других значениях она наблюдается уже в древнерусском языке: в значении 'охотно, с готовностью' - с XI в., а в значении 'усердно, ревностно' - с XII-XIII вв. (СРезНЕвский 3: 475, СлРЯ XI-XVII вв. 27: 29-30). Примечательно и то, что в «Ипатьевской летописи» (под 1425 г.) находим борже поидемъ в соответствии со сnъшнъе поидем в «Московском летописном своде» (см. СлРЯ XIXVII вв. 27: 30). По нашему мнению, это может свидетельствовать о том, что cnъшно в анализируемом значении не было распространено в восточнославянских языках до конца XV - начала XVI в., тогда как бързо, борзо в значении 'быстро; (по)спешно, торопливо' отмечается в древнерусских источниках уже в XI-XII вв., регулярно употреблялось в XIII-XIV вв. и бытовало в русской письменности в XV-XVII вв. (СлДРЯ 1: 329, СлРЯ XI-XVII вв. 1: 291-292). В письменности ВКЛ борзо, бордзе, борьзо 'хутка' широко представлено с конца XV в. (ГСБМ 2: 149, СУМ 3: 31).

Учитывая изложенное выше, а также то, что прилагательное сnъmный в значении 'быстрый, скорый; совершаемый быстро, поспешно', мотивирующем наречие, в русской письменности впервые представлено единичным употреблением в конце XV в., а более широкое распространение получает в деловой письменности только с начала второй четверти XVII в. (СлРЯ XIXVII вв. 27: 30), склоняемся к мнению, что спғшно 'поспешно, торопливо; быстро' также, как и неспъшно 'медленно, неторопливо; без поспешности' (см. выше), в русском языке, возможно, является семантическим полонизмом.

В старопольском языке śpiesznie 'szybko, cělěrütĕr' известно с конца 20-х гг. XV в. (SłStp 9: 34). В списке слов словаря польского языка XVI в. представлены формы śpiesznie и śpieszno (SłP XVI). В польских источниках XVII в. в значении 'prędko' отмечается śpieszno (SłP XVII). В интересующем нас значении śpiesznie, śpieszno и spiesznie, spieszno регистрируются в словарях, отражающих польский язык XVIII-XIX вв. (LiNDE 5: 378-379, KARŁOWICZ 6: 293, 751). В современной польской лексикографии śpieszno, spieszno 'z pośpiechem, pośpiesznie, szybko' сопровождаются пометами «daw.» или «przestarz.», ${ }^{32}$ a śpiesznie, spiesznie (реже) ‘то же' входит в активный состав лексики (SłJP 8: 1297, 1298).

В письменности ВКЛ спешне 'спешна' наблюдается с начала XVI в., а спешно 'то же' - с 80-х гг. того же столетия, причем в XVI-XVII вв. это наречие в обеих формах отмечается в основном в источниках, язык которых

${ }^{32}$ В настоящее время это наречие употребляется только в составе фразеологизма: śpieszno komuś do kogoś, czegoś (gdzieś) 'ktoś się śpieszy do kogoś, czegoś (gdzieś)' (SłJP 8: 1298). 
в значительной степени насыщен полонизмами, или в переводных памятниках, в том числе и с польского языка (СМС 2: 244, ГСБМ 32: 141). В украинском языке XVIII- XIX вв. сnъшно, спішно продолжало бытовать в интересующем нас значении (Тимченко 2: 356, Грінченко 4: 179), в этом значении спішно представлено и в словаре современного украинского языка (ВТССУМ 2005: 1369). В русском, как и в украинском языке, история сnъшно, спешно в анализируемом значении также последовательно прослеживается в XVIIIХХ вв. (ПоликАРПов 1704: л. 114 2-го счета, САР 5: 455, ССРЛЯ 14: 509). В словаре, отражающем белорусский язык XIX в., сnђшно регистрируется только в значении 'успьшно' (Носович 1870: 612). В толковом словаре современного белорусского языка приводится только прилагательное cneuнbl, в том числе и в значении 'які робіцца або адбываецца хутка; паспешлівы' (ТСБМ 5: 261), тогда как в двуязычном переводном белорусско-русском словаре представлено и наречие спешна 'спешно' (БРС 3: 619).

Опираясь на изложенные выше факты, мы допускаем вероятность заимствования лексемы спешне, спешно из польского языка в письменность ВКЛ в XVI веке. В данном случае следует говорить именно о возможном лексическом заимствовании, так как здесь это слово было известно только в одном значении. Что касается русского языка, то не исключено, что мы имеем дело с семантическим заимствованием из польского языка, которое могло осуществиться благодаря посредничеству канцелярского языка ВКЛ и «простой мовы».

То $[1]^{33}$ мест. указат. в знач. сущ., нескл. с. Обозначает указание на что-л. высказанное ранее, на сообщенные только что факты, обстоятельства, ситуацию и т. д. и употребляется в роли подлежащего; это: «Кратко рещи, вся намъ благая готовит, // ихже око не видить, и ухо не слыше и на сердце человъку не взыде. То есть, истинное насльдие, и приятие славы, во царствђ славном господа нашего» (ПсФ: лл. 6 - 6 об.).

В монографии «Семантические полонизмы в русском приказном языке первой половины XVII века» мы приводим аргументы, свидетельствующие в пользу того, что местоимение то в указанном выше значении в русском письменном языке XVII в., вероятнее всего является семантическим полонизмом (ГАРБУль 2009: 108-110).

Эту информацию можно дополнить данными об употреблении указательных местоимений той и тотъ в значении несклоняемого существительного среднего рода в роли подлежащего в письменности ВКЛ. В материалах исторического словаря белорусского языка одно такое употребление, по нашему мнению, представлено в словарной статье местоимения той 'у знач. наз. Ужываецца для указання на думку, дзеянні, абставіны, падзеі і пад., пра

${ }^{33}$ Е. А. Целунова рассматривает оба случая употребления выражения то есть, встречающиеся в «Предисловии к читателю» (ПсФ: л. 5, л. 6 об.), как союз (ЦЕлуновА 2006: 600). По нашему мнению, в роли союза то есть выступает только на л. 5. 
якія гаварылася раней або якія раскрываюцца далей” в иллюстрации из «Аповесци аб трох каралях-валхвах» конца XV в., другое - в словарной статье местоимения тоть 'паказвае на прадмет, асобу, час, што вылучаюцца з ліку іншых’ в примере из делового акта последней четверти XV в. (ГСБМ 33: 344, 400). Опираясь на эти сведения, можно предположить, что в данном случае также имеем дело с семантическим калькированием с польского. Если наше предположение верно, то семантическое заимствование в русский письменный язык могло осуществиться при посредничестве письменности ВКЛ.

\section{4. Выводы}

Подводя итог анализу заимствований из польского языка, обнаруженных в паратексте ПсФ, сформулируем некоторые обобщающие выводы:

1. В процессе исследования лексического состава паратекста ПсФ (запись, указывающая место и время перевода, имя переводчика, «Объяснение переводчика», «Предисловие к читателю») было обнаружено 29 полонизмов: 18 из которых, по нашему мнению, являются лексическими (из них два случая - не прямые заимствования [глупы $\check{u}^{34}$, читатель $\left.{ }^{35}\right]$, a, вероятнее всего, результат стимулирующего влияния польского языка) и 11 - семантическими заимствованиями из польского языка. При этом 8 лексических и 9 семантических полонизмов в ПсФ были выявлены впервые. Из них все 8 лексических и 6 семантических полонизмов вообще установлены впервые.

По отношению к общему количеству полонизмов в ПсФ, которые ранее были обнаружены Т. А. Исаченко и Е. А. Целуновой (ИсАченко 1984: 253254, ИСАчЕНКо 1987: 75-93, 96, 97; ЦЕЛУНовА 2006: 128-134), паратекстуальные полонизмы, отмеченные нами, составляют около 20,9\%. Тогда как по отношению ко всему лексическому составу ПсФ полонизмы, по данным Е. А. Целуновой, составляют около 3\% (ЦЕлуновА 2006: 132). Судя по этим цифрам, можно говорить о том, что полонизмы занимали достаточно значительное место в активном лексиконе переводчика.

2. Из полонизмов, засвидетельствованных в паратексте ПсФ, в самом тексте Псалтыри отмечаются следующие лексические заимствования: въдомость, геретикь, глупство, глупьй, господарство, естли/естьли, инструменть (иструменть), приигрывати, читатель (см. ЦЕлуновА 2006: 456, 457 , 459, 460, 474, 490, 558, 619), а также такие семантические полонизмы, как например, играние и недостаточный (ЦЕлуновА 2006: 484, 518). Бо́льшая

\footnotetext{
${ }^{34}$ Что касается глупый то, по нашему мнению, польский язык при посредничестве письменности ВКЛ мог стимулировать возвращение этой лексемы в активное употребление в русском письменном языке в XVI-XVII вв.

${ }^{35}$ По поводу лексемы читатель нет оснований говорить о прямом заимствовании из польского в восточнославянские языки. В данном случае польское влияние могло проявиться в том, что однокоренные существительные польского языка послужили моделью для образования этого слова в книжном языке ВКЛ, откуда оно, видимо, попало в русскую письменность XVII в.
} 
часть приведенных выше полонизмов встречается непосредственно в тексте и /или в глоссах ${ }^{36}$ от одного до двух-трех раз и только лексема инструменть (иструменть) зафиксирована 6 раз, а естли/естьли отличается еще более высокой частотностью употребления - 41 раз.

3. Что касается происхождения заимствований, отмеченных в паратексте ПсФ, то среди лексических заимствований около $78 \%$ составляют внутриславянские дериваты (за исключением лексем гересь, геретикъ, инструменть [иструментъ], школа), среди семантических калек внутриславянские дериваты составляют $100 \%$.

4. В настоящее время не вызывает сомнений роль письменности ВКЛ (актового языка и «простой мовы») как активного посредника в польско-русских языковых контактах в XVI-XVII вв. (ГАРБУль 2009: 425, ГАРБуль 2014: 253). Так, 17 из 18 лексических и 10 из 11 семантических полонизмов, обнаруженных в паратексте ПсФ, вероятнее всего, попали в русский письменный язык XV-XVII вв. благодаря посредничеству актового языка ВКЛ и /или «простой мовы».

Более того, непосредственно из письменности ВКЛ в русский письменный язык указанного выше периода, по нашему мнению, попали или благодаря ее стимулирующему влиянию вновь вошли в активное употребление такие лексемы, как читатель, а также, видимо, любезный в значении 'милый, дорогой' и, возможно, в значении 'уважаемый' в составе обращения ${ }^{37}$ (ПсФ: лл. 7, 7 об. [2 раза], 8, 8 об.), прочитание 'чтение; прочтение' 38 (ПсФ: Л. 5) и услаждение 'радость, утеха; удовольствие, наслаждение' (ПсФ: л. 6 об.).

\footnotetext{
36 Заметим, что глоссы также являются одним из элементов паратекста, но их исследование пока не входило в нашу задачу.

${ }^{37}$ В первом из указанных выше значений любезный впервые отмечено в письмах А. Курбского, а в качестве обращения в том же значении - в памятнике XVII в., известном в списке XVIII в. (СлРЯ XI-XVII вв. 8: 325); во втором значении наиболее раннюю фиксацию до сих пор относили к последней четверти XVIII века (СлРЯ XVIII в. 12: 7). В письменности ВКЛ любезный 'прыемны, мілы; дарагі' регистрируется с первой четверти XVI в., в составе обращения в этом значении - со второй половины XVII в., а в значении - 'шаноўны, паважаны' с 90-х гг. XVI в. (ГСБМ 17: 156). В польском языке XVI-XVIII вв. lubiezny, lubieżny в интересующем нас употреблении (в составе обращения) не обнаружено.

${ }^{38}$ В письменных источниках это существительное впервые фиксируется в памятнике XII в. (автор Климент Смолятич), дошедшем до нас в списке XV в., затем под 1218 г. отмечается в «Никоновской летописи» (в списке XVI в., вариант XVII в.), первый же точно датированный текст, где засвидетельствовано это слово, - «Вести-Куранты» 1644 г. (СлРЯ XI-XVII вВ. 20: 287). В письменности ВКЛ прочитане, прочитание, прочитанье, прочытанье 'то же' регулярно фиксируется с 1489 г. и в XVI-XVII в. имело широкое распространение как в деловых актах, так и в текстах на «простой мове» (ГСБМ 29: 284, Тимченко 2: 253). В польских источниках наиболее раннее употребление przeczytanie 'zapoznanie się z treścią tekstu przez czytanie' отмечается в конце 50-х гг. XVI в., более регулярно это существительное наблюдается в польском языке с 70-80-х гг. того же столетия и в XVII в. (SłP XVI 31: 164). Учитывая приведенную информацию, можно предположить, что анализируемое существительное если и не было заимствовано в русский письменный язык из письменности ВКЛ в XV в., то в XVIXVII вв. канцелярский язык ВКЛ и «простая мова» могли по меньшей мере способствовать активизации употребления прочитание в русском письменном языке.
} 
Надо отметить, что в ряде случаев межславянские языковые контакты, в результате которых осуществлялись лексические и семантические заимствования, отмеченные в паратексте ПсФ, носили еще более сложный характер. Так, при заимствовании лексем набытие, обыклой и потреба 'нужно, необходимо; следует', вероятнее всего, являющихся богемизмами, в роли посредника выступала не только письменность ВКЛ, но и польский язык. ${ }^{39}$

5. В заключение, опираясь на полученные нами результаты исследования и работы предшественников в этой области, выскажем некоторые предположения о происхождении и социальном положении Аврамия Фирсова. Т. А. Исаченко на основе данных изучения языка ПсФ пришла к выводу, что переводчик не был носителем польского языка, на что указывают немногочисленные, но характерные ошибки ${ }^{40}$ в тексте перевода. По ее мнению, Аврамий Фирсов не был и украинцем, о чем свидетельствует употребление им глагола возбуритися в значении 'наброситься, накинуться на кого-л.', тогда как в украинском языке данный глагол имел другое значение (см. ИсАченкоЛисовАя-Лисовой 1987: 102). На наш взгляд, возбуритися в ПсФ употреблено в том значении, которое было характерно для него в письменности ВКЛ и ко времени создания перевода уже было зафиксировано в русском письменном языке. ${ }^{41}$ В то же время Т. А. Исаченко указывает на наличие в ПсФ

${ }^{39}$ Примечательно, что первым лексикографическим источником, в котором зарегистрировано существительное услаждение, был «Лексикон» П. Берынды: «оуслажденїе: оутьха, роскошованье, оутъшенье» (БЕРЫндА 1627: л. 272). В письменности ВКЛ услаждение 'асалода, уцеха' впервые засвидетельствовано в конце XV в. в «Аповесці аб трох каралях-валхвах» (ПГССЛ 2: 418). В пользу нашего предположения может свидетельствовать также и то, что уже в древнерусском языке в том же значении употреблялись лексемы наслаждение (с XI в.) и наслажение (с XII-XIII вв.), первая из них бытовала в русской письменности и в XV-XVII вв. и до сих пор входит в активный состав русской лексики, судьба второй прослеживается только до XVII в. (СлДРЯ 5: 193-194, СлРЯ XI-XVII вв. 10: 252-253, СлРЯ XVIII в. 14: 47-48, БАС 11: 367). В письменности ВКЛ наслажение 'асалода' известно с конца XV в., а наслаждение 'то же' - с середины XVII века и отмечаются спорадически (ГСБМ 19: 290, ПГССЛ 1: 431). В польских памятниках глаголы osładzać и osłodzić в переносных значениях 'czynić coś łagodniejszym, spokojniejszym', 'uczynić coś mniej przykrym', 'uczynić przyjemnym' фиксируются с 60-80-х гг. XVI в. и в этом столетии представлены единичными употреблениями (SłP XVI 22: 154-155). Существительное ostodzenie, ostodzienie, образованное от ostodzić, в словаре отражающем язык XVI в., приводится без иллюстраций (SłP XVI 22: 154). Сопоставление приведенных данных позволяет, на наш взгляд, предполагать, что если рассматриваемое слово в русском языке является межславянским заимствованием, то его вероятным источником могла быть письменность ВКЛ.

${ }^{40}$ Т. А. Исаченко приводит три ошибки: пол. zrzenice $w$ oku переводится как зрение во оке вместо зеница ока, пол. tak iż переводится как тако же вм. так что и obliczać понимается как 'разоблачать, выявлять' вместо 'считать, исчислять' (см. ИСАЧЕНКО-ЛиСОВАЯ-ЛисовОЙ 1987: 101-102).

${ }^{41}$ В исторических словарях всех восточнославянских языков данный глагол представлен в том значении, в котором он зафиксирован в ПсФ: взбуритися, узбуритися 'узбудзіцца, разгневацца на каго-н.; паўстаць супраць каго-н.' (ГСБМ 3: 182), збуритися 'абурыцца, разгневацца, стаць абураным' (ГСБМ 12: 49); взбуритися 'збунтоватися' (СУМ 4: 15), збуритися '(підняти бунт, збунтоватися) збуритися' (СУМ 11: 83-84); взбуритися 'не подчиниться приказам’ (СОРЯ 2: 155). 
следов влияния «простой мовы» в ее белорусском варианте: гересь, геретики при укр. ересь, еретики и велерыбъ при укр. велиорыбъ (ИСАЧЕНКО-ЛисовАЯЛисовой 1987: 102). По поводу гересь, геретикъ мы высказали свое мнение в данной публикации (см. выше). В связи с велерыбъ (см. ГСБМ 3: 81, СУМ 3: 219, Аникин 6: 208) мы согласны с Т. А. Исаченко. В итоге этот автор приходит к выводу, что А. Фирсов был великорусом, о чем свидетельствуют и выявленные ею в ПсФ многочисленные черты живой московской речи (см. ИСАЧЕНКО-ЛИСОВАЯ 1984: 248-257). Вместе с тем Т. А. Исаченко допускает, что А. Фирсов мог быть белорусом, давно жившим в России (см. ИсАЧенкоЛисовАя-Лисовой 1987: 102).

Наши материалы в основном подтверждают выводы Т. А. Исаченко, но в то же время они позволяют дополнить, уточнить и скорректировать некоторые ее данные. Так, мы поддерживаем мнение о том, что А. Фирсов не был носителем польского языка, но достаточно хорошо владел им (несмотря на отдельные ошибки, допущенные в тексте перевода), о чем свидетельствует довольно большое количество полонизмов, обнаруженных в паратексте ПсФ. Причем даже те полонизмы, которые следует отнести к окказионализмам в русском письменном языке того времени (гересь, геретикъ, приигрывати и належащий в анализируемом значении), видимо, входили в активный словарь А. Фирсова. ${ }^{42}$ Кроме того, информация, представленная в предыдущем пункте выводов, на наш взгляд, подтверждает предположение Т. А. Исаченко о том, что переводчик ПсФ мог быть выходцем из ВКЛ, возможно, с западных территорий, но бо́льшая часть его жизни и профессиональной деятельности, очевидно, прошла в Московской Руси. Кстати, хорошее владение А. Фирсовым польским языком может объясняться его происхождением.

Как затронутый выше вопрос о происхождении переводчика ПсФ, так и вопрос о его социальном положении и роде деятельности до сих пор остается дискуссионным. Е. А. Целунова, занимавшаяся текстологическим и лингвистическим анализом ПсФ, отвергает сложившееся еще во второй половине XIX в. мнение о том, что А. Фирсов был переводчиком Посольского приказа (см. ЦЕлуновА 2006: 21-23). Свое заключение она обосновывает тем, что данные об А. Фирсове не включены в списки переводчиков Посольского приказа (ЦЕлуновА 2006: 141-142). В связи с этим следует заметить, что историки, занимающиеся изучением персонала Посольского приказа в XVII в., указывают на трудности, которые возникают при установлении состава толмачей, переводчиков и подьячих этого ведомства по той причине, что по ряду лет сохранность документации является отрывочной, то есть нет полной информации, а, кроме того, в ряде случаев один и тот же человек упоминается под несколькими именами (см. БЕЛяков 2001: 208, 210; БЕЛяков 2002,

${ }^{42}$ Е. А. Целунова считает, что подавляющее большинство полонизмов как текстуальных, так и паратекстуальных являются окказионализмами (ЦЕлуновА 2006: 132). Но это мнение в отношении некоторых полонизмов ПсФ не подтверждается данными исследований дипломатической корреспонденции Московского государства конца XVI- первой половины XVII в. (см. ГАРБУЛЬ 2009, ГАРБУЛЬ 2014). 
Куненков 2012). Что касается служащих Посольского приказа, которые известны на данный момент, примечателен следующий факт: в документах посольств 1668 г. и 1673 г. в Австрию и Венецию фигурирует подьячий Новгородской (-ого) чети (приказа) Федор Фирсов (ПДС IV: стлб. 685, 686, 687, 692, 693, 742, 860; см. также БЕляков 2001: 209). Мы пока не можем ответить на вопрос: существует ли какая-либо связь между А. Фирсовым и Ф. Фирсовым. Это задача для последующих изысканий как историков, так и исследователей истории русского литературного языка. Но в любом случае, учитывая приведенную выше информацию, на наш взгляд, нельзя категорически отвергать гипотезу о том, что А. Фирсов мог служить в Посольском приказе или по меньшей мере мог выполнять какие-либо поручения по линии этого ведомства. Тем более что именно сотрудники Посольского приказа, отличавшиеся широкой образованностью, социальной активностью, а некоторые из них и литературной одаренностью, помимо прямых служебных обязанностей, занимались переводами, созданием оригинальных сочинений, составлением кНиГ По русской истории (см. ГАРБУЛЬ 2009: 14-15, КИСЕЛЕВА-ЧУМАКОВА 2009: $30-31)$.

\section{Источники}

ПсФ = Псалтырь в переводе Аврамия Фирсова. ГИМ. Син. № 710 .

\section{Словари}

Аникин $=$ Аникин А. Е. Русский этимологический словарь. Вып. 1-9. Москва, 20072015.

БАС = Большой академический словарь русского языка. Т. 1-23. Санкт-ПетербургМосква, 2004-2014.

БЕРЫНДА 1627 = БЕРЫНДА Памва: Лексіконъ славеноросскій и именъ тлъкованїе. Київ, 1627.

БПРС = ГЕССеН Д., СТЫПУЛА Р. Большой польско-русский словарь. Т. 1-2. МоскваВаршава, ${ }^{2} 1980$.

БРС = АтРАХОВІч К. К. [Кандрат Крапіва] (рэд.) Беларуска-рускі слоўнік. Т. 1-3. Мінск, ${ }^{3} 2003$.

ВТССУМ 2005 = БУСЕЛ В. Т. (ред.) Великий тлумачальний словник сучасної украӥнської мови. Київ, 2005.

ГРІНЧЕНКО = ГРІнЧЕНКО Б. Словарь украӥнської мови в чотирьох томах. Т. 1-4. Київ, 1996-1997.

ГСБМ = Гістарычны слоўнік беларускай мовы. Вып. 1-34. Мінск, 1982-2014.

Даль = Даль В. И. Толковый словарь живого великорусского языка. Т. 1-4. Москва, 1978-1980.

ЕСУМ = Етимологічний словник украӥнської мови. Т. 1-6. Київ, 1982-2012.

Носович 1870 = Носович И. Словарь бълорусскаго нарьчія. Санкт-Петербург, 1870.

ПГССЛ = БулыкА А. М. (рэд.) Падручны гістарычны слоўнік субстантыунай лексікі.

Т. 1-2. Мінск, 2013.

ПоликАРПОВ 1704 = ПолиКАРПОВ Федор: Лексіконъ треязычный... Москва, 1704. 
ПРЕОБРАЖЕНСКИЙ = ПРЕОБРАЖЕНСКИЙ А. Г. ЭТИмоЛОгичесКий словарь рУсского яЗыКа. Т. 1-2. Москва, 1959.

САР = Словарь Академии Российской, по азбучному порядку расположенный. Ч. 1-6. Санкт-Петербург, 1806-1822.

СлДРЯ = Словарь древнерусского языка (XI-XIV вв.). Т. 1-10. Москва, 1988-2013.

СлРЯ XI-XVII вв. = Словарь русского языка XI-XVII вв. Вып. 1-29. Москва, 19752011.

СлРЯ XVIII в. = Словарь русского языка ХVIII века. Вып. 1-20. Санкт-Петербург, 1984-2013.

СОРЯ = Словарь обиходного русского языка Московской Руси XVI-XVII веков. Вып. 1-6. Санкт-Петербург, 2004-2014.

СРЕЗНЕВСКИЙ = СРЕЗНЕВСКИЙ И. И. Материаль для словаря древнерусского языка. Т. 1-3. Санкт-Петербург, 1893-1912.

СРНГ = Словарь русских народных говоров. Вып. 1-46. Москва-Санкт-Петербург, 1965-2013.

ССМ = Словник староукраїнської мови XIV-XV cm. Т. 1-2. Київ, 1977-1978.

ССРЛЯ = Словарь современного русского литературного языка. Т. 1-17. Москва-Ленинград, 1950-1965.

СТС = ЦЕЙТЛИН Р. М., ВЕЧЕРКА Р., БЛАГОВА Э. (ред.) Старославянский словарь (по рукописям $X-X V$ веков). Москва, ${ }^{2} 1999$.

СУМ = Словник української мови XVI - першої половини XVII cm. Вип. 1-15. Львів, 1994-2010.

Тимченко = Тимченко Є. К. Материали до словника писемної та книжної українськой мови XV-XVIII cm. Кн. 1-2. Київ-Нью-Йорк, 2002-2003.

ТСБМ = Тлумачальны слоўнік беларускай мовы. Т. 1-5. Мінск, 1977-1984.

ФАСМЕР = ФАСМЕР Макс: Этимологический словарь русского языка. Т. 1-4. Москва, $1964-1973$.

ЧЕРнЫХ = ЧЕРнЫХ П. Я. Историко-этимологический словарь современного русского языка. Т. 1-2. Москва, 1999.

ЭСБМ = Этылмалагічны слоўнік беларускай мовы. Т. 1-13. Мінск, 1978-2010.

ЭСлРЯ = Этимологический словарь русского языка. Вып. 1-10. Москва, 1963-2007.

ЭССЯ = Этимологический словарь славянских языков. Вып. 1-39. Москва, 1974-2014.

BAŃKOWSKI = BAŃKOWSKI A. Etymologiczny słownik języka polskiego. T. 1-2. Warszawa, 2000.

BORYŚ 2005 = BORYŚ W. Słownik etymologiczny języka polskiego. Kraków, 2005.

BRÜCKNER 1974 = BRÜCKNER A. Stownik etymologiczny języka polskiego. Warszawa, 1974.

KARŁowiCz = KarŁowiCz J., KRYŃSKi A., NiEDźwIEDZKI W. (red.) Słownik języka polskiego. T. 1-8. Warszawa, 1900-1927.

LiNDE = LindE S. B. Słownik języka polskiego. T. 1-6. Lwów, 1854-1860.

POKORNY $=$ POKORNY J. Indogermanisches etymologisches Wörterbuch. Bd. 1. Bern, 1959.

RECZEK 1968 = RECZEK S. Podręczny słownik dawnej polszczyzny. Wrocław-WarszawaKraków, 1968.

REJZEK 2001 = REJZEK J. Český etymologický slovnik. Praha, 2001.

SŁAWSKI = SŁAWSKI F. Stownik etymologiczny języka polskiego. T. 1-5. Kraków, 1952-1982. SłJP = Słownik języka polskiego. T. 1-11. Warszawa, 1958-1969.

SłP XVI = Słownik polszczyzny XVI wieku. T. 1-36. Wrocław-Warszawa-Kraków-Gdańsk, 1966-2012. http://www.spxvi.edu.pl/indeks.

SłP XVII = Elektroniczny słownik języka polskiego XVII i XVIII wieku. http://sxvii.pl. 
SłPaska = Słownik języka Jana Chryzostoma Paska. T. 1-2. Wrocław-Warszawa-Kraków, 1965-1973.

SłStp = Stownik staropolski. T. 1-11. Warszawa, 1953-2002.

StčSl = Staročeský slovnik. D. 3-5. Praha, 1977-2004.

\section{Литература}

БЕЛяков 2001 = БЕЛяков А. В. Подьячие Посольского приказа 2-й половины XVII в. В кн.: Исследования по источниковедению России (до 1917 г.). Москва, 2001. 208220.

БЕЛяков 2002 = БЕЛяков А. В. Служащие Посольского приказа второй трети XVII в. Диссертация кандидата исторических наук. Москва, 2002.

БулыКА 1972 = БулыкА А. М. Даўнія запазычанні беларускай мовы. Мінск, 1972.

БулыКА 1980 = БулыкА А. М. Лексічныя запазычанні у беларускай мове. Мінск, 1980.

ВИНОГРАДОВ 1999 = ВИНОГРАДОВ В. В. История слов. Москва, ${ }^{2} 1999$.

ГАРБУль $2009=$ ГАРБУль Л. Семантические полонизмы в русском приказном языке первой половины ХVII века. Vilnius, 2009.

ГАРБУЛЬ 2014 = ГАРБУЛь Л. Лексические полонизмы в русском приказном языке первой половины ХVII века. Vilnius, 2014.

Живов 1986 = Живов В. М. Новые материалы для истории перевода «Географии генеральной» Бернарда Варения. Известия АН СССР. Серия литературы и языка 1986/3: 246-260.

ЗОЛТАН 2002 = ЗоЛтАН А. К предыстории русск. государь. В кн.: УСПЕНСКИй Ф. Б., Литвина А. Ф. (ред.) Из истории русской культуры. Т. 2. Кн. 1. Киевская и Московская Русь. Москва, 2002. 554-590.

ЗолТАн 2014 = ЗолТАН А. Interslavica. Исследования по межславянским языковым и культурныл контактам. Москва, 2014.

ИСАЧЕНКО 1985 = ИСАчеНКО Т. А. Фирсов Аврамий Панкратьевич (XVII в.). Труды Отдела древнерусской литературы. Т. 40. Ленинград, 1985. 178-179.

ИСАЧЕНКО-ЛИСОВАЯ 1984 = ИСАЧЕНКО-ЛИСОВАЯ Т. А. «ПсаЛтирь Аврамия Фирсова» 1683 г. Особенности языка и перевода. Известия АН СССР. Серия литературь и языка 1984/3: 248-257.

ИСАЧЕНКО-ЛИСОВАЯ-ЛИСОВОЙ 1987 = ИСАЧЕНКО-ЛИСОВАЯ Т. А., ЛИСОВОЙ Н. Н. ТекстУальные полонизмы Псалтири Фирсова 1683 г. Книжные заимствования или диалектизмы? В кн.: Русская региональная лексика XI-XVII вв. Москва, 1987. 68-104.

КИСЕЛЕВА-ЧУМАКОВА $2009=$ КИСеЛЕВА М. С., ЧУМАКОВА Т. В. ВХожДеНИе России в интеллектуальное пространство Европы: между царством и империей. Bonpocbl философии 2009/9: 22-41.

КУНЕнков 2012 = КУНенков Б. А. Переводчики и толмачи Посольского приказа во второй четверти ХVII века. Функиии, численность, порядок приема. http://www. mkonf.iriran.ru/archive.php?id $=50$.

МушинСКАЯ 2010 = МушинСКАЯ М. С. Еще раз об отношениях Изборника 1073 г. и Изборника 1076 г. (к вопросу о датировке Краткой редакции Симеонова сборника). В кн.: Лингвистическое источниковедение и история русского языка 20062009. Москва, 2010. 81-99.

ПДС = Памятники дипломатических сношений древней России с державами иностранными. Памятники дипломатических сношений с Римскою империею (с 1661 по 1674 год). Т. 4. Санкт-Петербург, 1856. 
СоБОЛЕВСКий 1903 = СоБОЛЕвСкий А. И. Переводная литература Московской Руси XIV-XVII вв. Библиографические материальл. Санкт-Петербург, 1903.

ТАМАНЬ 1960 = ТАМАНЬ В. М. Полонизмы в языке русских памятников XVII века. Ученые записки ЛГУ 267. Серия филологических наук. Вып. 52. Ленинград, 1960. 98-124.

Топоров 1961 = Топоров В. Н. Локатив в славянских языках. Москва, 1961.

УСПЕНСКИЙ 2002 = УСПЕНСКИЙ Б. А. История русского литературного языка (XIXVII вв.). Москва, ${ }^{3} 2002$.

ЦЕЛУнова $2006=$ ЦЕЛУновА Е. А. Псалтырь 1683 года в переводе Аврамия Фирсова. Текст, словоуказатель, исследование. Москва, 2006.

Kochman 1971 = Kochman S. Polonizmy w języku rosyjskiej korespondencji dyplomatycznej (1487-1571). Cz. I. Sprawozdania Opolskiego Towarzystwa Przyjaciół Nauk 7 (1971): 37-54.

Kochman 1975 = Kochman S. Polsko-rosyjskie stosunki językowe od XVI do XVIII w. Stownictwo. Opole, 1975.

LEEMING 1976 = LEEMING H. Rola języka polskiego $w$ rozwoju leksyki rosyjskiej do roku 1696. Wyrazy pochodzenia łacińskiego i romańskiego. Wrocław-Warszawa-KrakówGdańsk, 1976.

SOBIK $1969=$ SoBIK M.-E. Polnisch-russische Beziehungen im Spiegel des russischen Wortschatzes des 17. und der ersten Hälfte des 18. Jahrhunderts. Meisenheim am Glan, 1969.

WITKOWSKI 1992 = WITKOWSKI W. Rosyjskie zapożyczenia semantyczne z języka polskiego. Z polskich studiów slawistycznych 8. Warszawa, 1992. 263-270.

WITKOWSKI $2006=$ WITKOWSKI W. Nowy słownik zapożyczeń polskich w języku rosyjskim. Kraków, ${ }^{2} 2006$. 